\title{
Structure and function of nematode communities across the Indian western continental margin and its oxygen minimum zone
}

\author{
R. Singh ${ }^{1}$ and B. S. Ingole ${ }^{2}$ \\ ${ }^{1}$ Senckenberg am Meer, DZMB, Südstrand 44, 26382 Wilhelmshaven, Germany \\ ${ }^{2}$ Biological Oceanography Division, National Institute of Oceanography, Goa, 403004, India \\ Correspondence to: R. Singh (rubail2010@gmail.com)
}

Received: 20 June 2015 - Published in Biogeosciences Discuss.: 23 July 2015

Revised: 20 November 2015 - Accepted: 15 December 2015 - Published: 15 January 2016

\begin{abstract}
We studied patterns of nematode distribution along the western Indian continental margin to determine the influence of habitat heterogeneity and low oxygen levels on the community's taxonomic and functional structure. A single transect, perpendicular to the coast at $14^{\circ} \mathrm{N}$ latitude was sampled from 34 to $2546 \mathrm{~m}$ depth for biological and environmental variables during August 2007. The oxygen minimum zone extended from 102 to $1001 \mathrm{~m}$. Nematodes (described and undescribed) were identified to species and classified according to biological and functional traits. A total of 110 nematode species belonging to 24 families were found along the transect. Three depth zones were identified: the shelf (depth range: $34-102 \mathrm{~m}$; highest nematode mean density: $176.6 \pm 37$ ind $10 \mathrm{~cm}^{-2}$ ), the slope (525-1524 m; $124.3 \pm 16$ ind $10 \mathrm{~cm}^{-2}$ ), and the basin (2001$2546 \mathrm{~m} ; 62.9 \pm 2$ ind $10 \mathrm{~cm}^{-2}$ ). Across the entire study area, the dominant species were Terschellingia longicaudata, Desmodora sp. 1, Sphaerolaimus gracilis, and Theristus ensifer; their maximum density was at shelf stations. Nematode communities in different zones differed in species composition. Chromadorita sp. 2 (2.78\%) and Sphaerolaimus gracilis $(2.21 \%)$ were dominant on the shelf, whereas Terschellingia longicaudata (4.73\%) and Desmodora sp. 1 $(4.42 \%)$ were dominant on the slope, but in the basin, $\mathrm{Ha}$ lalaimus sp. 1(1.11\%) and Acantholaimus elegans $(1.11 \%)$ were dominant. The information in a particular functional group was not a simple reflection of the information in species abundance. Ecological information captured by adult length, adult shape, and life-history strategy was less sitespecific and thus differed notably from information contained in other taxonomic groups. The functional composition of nematodes was strongly linked to the organic-
\end{abstract}

carbon and dissolved-oxygen concentration. Seven species were found exclusively in the oxygen minimum zone: Pselionema sp. 1, Choanolaimus sp. 2, Halichoanolaimus sp. 1, Cobbia dentata, Daptonema sp. 1, Trissonchulus sp. 1, and Minolaimus sp. 1. Correlation with a number of environmental variables indicated that food quantity (measured as the organic-carbon content and chlorophyll content) and oxygen level were the major factors that influenced nematode community structure and function.

\section{Introduction}

The continental margin exhibits great topographical heterogeneity in geomorphological features (e.g. canyons and seamounts, shelf, slope, rise, marginal highs) and their related environmental conditions (e.g. depth, pressure, temperature, salinity, light, dissolved oxygen, sediment characteristics) (Levin et al., 2001). This heterogeneous environment is of great ecological interest because of its wide range of gradients in living conditions and the high faunal diversity it supports on local, regional, and global scales (Vanreusel et al., 2010). The western Indian continental margin, located in the eastern Arabian Sea of the northern Indian Ocean, includes a series of complex environments including shelf, slope, and a permanent oxygen-depleted zone. In general, oxygen minimum zones (OMZs) are defined as layers of the water column where dissolved oxygen (DO) concentrations fall below $0.5 \mathrm{mLL}^{-1}$. Oxygen minima are common in the world ocean (Kamykowski and Zentara, 1990) and are found at intermediate depths in the Arabian Sea, off western Mexico, and off Peru and northern Chile. The Arabian Sea OMZ is one of the 
strongest and most intense in the world, with oxygen concentrations $<2 \mu \mathrm{M}$ in its core (Helly and Levin, 2004; Paulmier and Ruiz-Pino, 2009; Zettler et al., 2009). The OMZ in the Arabian Sea is spread over $285000 \mathrm{~km}^{2}$ of the benthic area. The OMZ occupies a depth range of approximately $150-1000 \mathrm{~m}$ and is the thickest of the three major OMZs of the open ocean (Banse et al., 2014). Although the Arabian Sea covers only $2 \%$ of the surface area of the world ocean, it is one of the most biologically productive regions (Ryther and Menzel, 1965).

The entire western Indian continental margin (shelf to slope) supports a high benthic biodiversity (Ingole et al., 2010). Free-living nematodes are prominent members of the meiobenthos along the ocean continental margin, often constituting $>90 \%$ of all metazoa (Vincx et al., 1994). Moreover, they are more tolerant to anoxic conditions than macro- and other meiofauna (Giere, 1993; Moodley et al., 1997). Studies like those of Jensen (1987) and Murrell and Fleeger (1989) reported effects of low-oxygen conditions on nematofauna in sandy sediments at shallow depths and from the Gulf of Mexico, respectively, and showed that nematode abundance was unaffected by oxygen concentration. Cook et al. (2000) studied nematodes from the Arabian Sea OMZ and concluded that nutrient input is more important than oxygen concentration, but in another experimental study in the tidal flats, hypoxia caused a dramatic change in the nematode community composition, including a reduction in diversity and abundance of all dominant nematodes except for the genus Odontophora (Van Colen et al., 2008). Neira et al. (2013) found that nematode generic and trophic diversity was lowest at the most oxygen-depleted site along a central Chile margin. De Troch et al. (2013), in a short incubation experiment, found that nematodes were not affected by anoxic conditions. They further concluded that responses to stress depend on the species and the frequency of the hypoxic periods. In contrast to several studies on the effects of anoxia on Nematoda at higher taxonomic levels, little is known about their response at the species level.

Several transitional settings in the western Indian continental margin, including the shelf, slope (long stretch of OMZ), and basin, provide multiple oxygen and other environmental gradients. These settings allowed us to investigate how oxygen and environmental factors affect and modulate the structure and function of nematode communities at the species level. An exclusive study from the Indian western continental margin with reference to nematode tolerance in the OMZ is therefore important. Furthermore, nematode community structure from the western Indian continental margin (including the OMZ) of the Arabian Sea remains unstudied. In general, information on nematode species data is missing from the Arabian Sea, and the present study can provide important basic information on nematode community structure.

Traditional taxonomy-based methods of nematode community analyses may not, however, fully account for nema- todes' diverse roles in ecosystem function (Schratzberger et al., 2007), so the inclusion of functional analysis has been recommended (de Jonge et al., 2006).

Many previous studies (e.g. Bremner et al., 2003; Boström et al., 2006) on macrobenthic invertebrates have shown that linking the taxonomic and functional aspects can reveal different relationships between assemblages, and for an exploration of the relationship between biodiversity and ecosystem function, nematodes could be considered the ideal model organisms (Danovaro et al., 2008).

Nematode species in functional groups share several morphological traits (Chalcraft and Resetarits Jr., 2003), and the use of these traits may provide additional information on changes in biodiversity and also facilitate better comparison with other geographical regions (Bremner, 2008). Giere (1993) showed that a classification based on buccal structures of marine nematodes had applications in a variety of marine habitats. Thistle and Sherman (1985) found that nematode tail shape formed an important biological trait especially in locomotion and reproduction. Furthermore, body size is known to influence many traits of an animal, such as its life history, physiology, and energy requirements, whereas species morphotype represents adaptations to life in oxygen-poor and sulfide-rich sediments (Jensen, 1987). Bongers (1990) and Bongers et al. (1991, 1995) classified the genera (on a scale of 1 to 5) from r-selected "colonisers" to K-selected "persisters", according to their life history, to assess the condition of terrestrial and freshwater habitats but also of marine environments from the shelf.

In the study here, we examined the nematode community structure along a habitat gradient using traditional diversity measures, taxonomic properties, and the functionalgroup concept based on biological traits so as to answer the following questions.

Does a heterogeneous gradient like the shelf, slope, and deep basin of the western Indian continental margin affect the marine nematode community structurally and functionally?

What are the patterns and drivers of variation in nematode composition and diversity (structural and functional) along the western Indian margin; i.e. are oxygen levels the main driver, or are other factors (sediment, productivity, etc.) more important?

\section{Materials and methods}

\subsection{Study area}

The bottom topography of the Arabian Sea includes the Carlsberg Ridge in the southern part, the Murray Ridge in the northern part, and an unsloped region in between (from 14 to $21^{\circ} \mathrm{N}$ ). The continental shelf is $120 \mathrm{~km}$ wide in the southern part, narrows to about $60 \mathrm{~km}$ at $11^{\circ} \mathrm{N}$, and widens to about $350 \mathrm{~km}$ in the Gulf of Khambhat (Shetye and Shenoi, 1988). 
Surface circulation is controlled by the seasonal variation in various types of winds. During the southwest monsoon, biological productivity in the Arabian Sea lies mainly around the centres of seasonal upwelling off the Arabian Peninsula, Somalia, and southwest India (Qasim, 1977). The Arabian Sea is characterised by a very pronounced midwater oxygen minimum zone (OMZ) between 150 and $1250 \mathrm{~m}$; it is over $1000 \mathrm{~m}$ thick and extends vertically from the bottom of the euphotic layer $(\sim 100 \mathrm{~m})$ to $\sim 1000 \mathrm{~m}$ (Wishner et al., 1990). The variations in the intensity of the OMZ are related to upwelling intensity and thermocline ventilation by Indian Ocean water (Reichart et al., 1998).

\subsection{Sampling}

A single transect was selected perpendicular to the coast of the Arabian Sea at $14^{\circ} \mathrm{N}$ latitude (Fig. 1). A detailed benthic sampling was performed on board ORV Sagar Kanya during August 2007 (cruise no. SK 237). Eight stations were sampled, at water depths of $34,48,102,525,1001$, 1524,2001 , and $2546 \mathrm{~m}$, by means of a spade box corer $(50 \times 50 \times 50 \mathrm{~cm})$. According to Rao and Veerayya (2000), the transect can be divided into five regions: shelf (34, 48 , and $102 \mathrm{~m})$, upper slope (525 m), mid slope (1001 m), lower slope $(1524 \mathrm{~m})$, and basin (2001-2546 m). For our purposes, however, all three slope depths were considered a single region; the study area was therefore divided into only three depth zones: shelf, slope, and basin (Ingole et al., 2010). On the basis of oxygen concentration, the OMZ was defined as extending from 102 to $1001 \mathrm{~m}$. For nematode assemblages, a PVC $(5.7 \mathrm{~cm}$ diameter $)$ was used for sub-sampling. At each station, two sub-samples were cut into $1 \mathrm{~cm}$ slices down to $5 \mathrm{~cm}$ sediment depth and fixed in buffered $4 \%$ formalin. Separate sub-cores were collected for organic carbon $\left(\mathrm{C}_{\mathrm{org}}\right)$ and sediment chlorophyll $a(\mathrm{Chl} a)$, and they were frozen at $-20^{\circ} \mathrm{C}$. Bottom-water dissolved oxygen (DO) measurements were taken with a DO sensor attached to the conductivity-temperature-depth (CTD) sonde for depths down to $1524 \mathrm{~m}$. Water below this depth was collected in Niskin bottles and used for DO.

\subsection{Laboratory analysis}

Dissolved oxygen was analysed by Winkler's method (Strickland and Parsons, 1968). Sample bottles were stored upright in an ice chest in a dark location and were analysed after a period of $8-9 \mathrm{~h}$. Chl $a$ was estimated by means of an acetone extraction method using a fluorometer (HolmHansen and Riemann, 1978). Total-carbon analyses were carried out in freeze-dried sediments with a NCS 2500 (ModelEA/NA1110) CNS (carbon-nitrogen-sulfur) analyser. Inorganic carbon was analysed with a $\mathrm{CO}_{2}$ Culometer analyser, and the percentage of $\mathrm{CaCO}_{3}$ was calculated. The percentage of $\mathrm{C}_{\text {org }}$ was calculated by subtraction of inorganic from

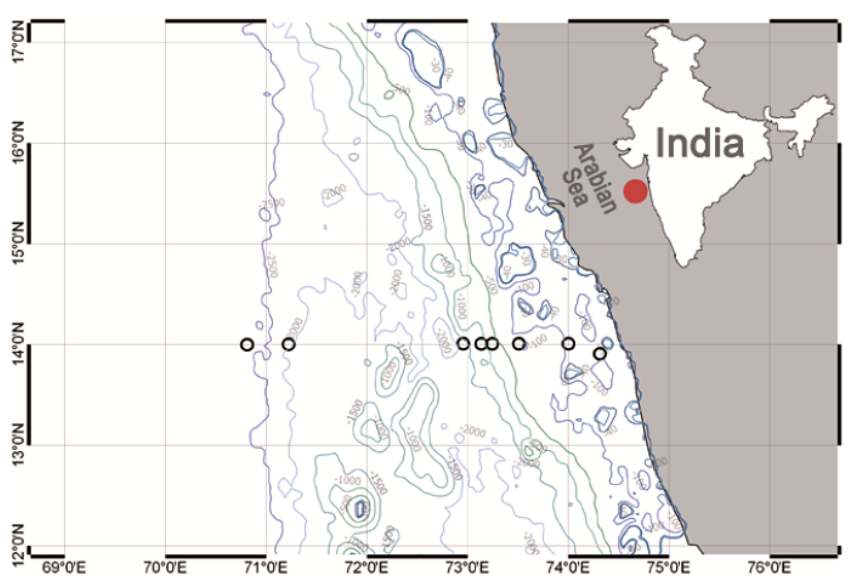

Figure 1. Map showing the depth contours and positions of the eight sampling stations (left; black circles) on the coast of the Arabian Sea (marked as red circle on the map on the right).

total carbon. Sediment granulometry was determined by a Malvern laser analyser (Model-Hydro 2000MU).

Meiofauna samples were washed over a $500 \mu \mathrm{m}$ mesh and then sieved on a $32 \mu \mathrm{m}$ mesh, which retained the meiofauna fraction. This retained fraction was then elutriated by the centrifugation-flotation technique with LUDOX (Vincx and Hall, 1996; Heip et al., 1985). Nematodes were counted through a stereomicroscope and were picked and mounted on permanent glass slides for taxonomic identification. In all, 1798 nematodes were examined. They were identified up to described and morphotype species level using the pictorial keys of Platt and Warwick (1983) and the NeMys database (Vanaverbeke et al., 2015). For identification to species level, each morphotype was sketched and measured by means of a camera lucida so that all specimens of the same genus could be compared.

\subsection{Nematode functional trait analysis}

Nematode species were classified according to their buccal morphology, tail shape, adult length, adult shape, and life history.

\subsubsection{Feeding types}

Individual nematode species were assigned to four feeding categories according to Wieser (1953): selective deposit feeders (1A), non-selective deposit feeders (1B), epigrowth feeders $(2 \mathrm{~A})$, and predators or omnivores (2B).

\subsubsection{Tail shape}

Thistle and Sherman (1985) developed a functional-trait scheme based on tail shape. Tail types are diverse and variable and have been suggested as an effective method of characterising nematode communities. Nematodes were assigned to four tail-shape groups, which are common in free-living 
marine nematodes: short or round, elongated or filiform, conical, and clavate.

\subsubsection{Total length and body shape}

Total length and the maximum body width for adult nematodes were measured, and from the results we calculated the length : width ratio. Soetaert et al. (2002) suggested three body-shape morphologies: stout, slender, and long and thin. The length : width ratio is a measure of a nematode's body shape; long and thin animals have high ratios, and stout animals have low ratios. From the measured length, each species was therefore assigned to one of four length groups $(<1,1-$ $2,2-4$, and $>4 \mathrm{~mm}$ ) and three shape categories (stout, with a length : width ratio < 18; slender, with a length: width ratio of 18-72; and long and thin, with a length : width ratio $>72$ ).

\subsubsection{Life history (C-P score)}

Nematodes were allocated to life-history groups according to Bongers (1990) and Bongers et al. (1991); genera are classified on a scale of 1 to 5 from colonisers (1: short life cycle, high reproduction rates, high colonisation ability, tolerance of various types of disturbance) to persisters (5: long life cycles, low colonisation ability, few offspring, sensitivity to disturbance). The species belonging to the monhysterid family were assigned to the C-P 2 class ("general opportunists") as advised by Bongers et al. (1995) and later restated by Pape et al. (2013); no nematodes belonged to C-P class 1 ("enrichment opportunists").

A biological-traits matrix was constructed by assignment to each nematode species of its affinity to each trait category and the percentage (\%) contribution of each species.

\subsection{Statistical analysis}

The similarity analysis at the species level was based on two types of similarity measures: the Bray-Curtis dissimilarity (standardised, square-root transformed) (Bray and Curtis, 1957), based on the relative abundances of nematode genera, and ordination using the Jaccard similarity index based on presence or absence (Clarke, 1993). Differences between the samples were visualised by means of non-metric multidimensional scaling (nMDS) plots.

We applied a permutational multivariate analysis of variance (PERMANOVA) designed with two factors - "station" (all stations in the zone combined) nested in "zones" (shelf, slope, and deep basin) - to detect the statistical significance of differences in pairwise comparisons of nematode communities from different zones (PERMANOVA; Anderson, 2005; Anderson et al., 2008).

Diversity was expressed in terms of the expected number of species in a sample, ES (51). The other diversity indices were calculated by means of Margalef's index (Margalef, 1968) for species richness $(d)$, Pielou's index (Pielou, $1966)$ for species evenness $\left(J^{\prime}\right)$, and the Shannon-Wiener in- dex (Shannon and Weaver, 1963) for species diversity ( $H^{\prime}$ by using $\log _{e}$ ).

Environmental variables were then subjected to principalcomponent analysis (PCA) for identification of the spatial patterns based on environmental data. A lower triangular Euclidean distance matrix relating to the ordination was constructed (Clarke and Green, 1988). Before calculation of the Euclidean distance resemblance matrix, the data were checked for uniform distribution and normalised (by subtraction of the mean and division by the standard deviation, for each variable) before analysis.

Analysis of collinearity was tested by means of a draftsman plot and the associated standard product moment correlation coefficients between all pairs of variables, and pairs with correlations $r^{2}>0.9$ were omitted from the model. If distribution of residuals was skewed, natural logarithm transformation was applied to the response variable until assumptions were met by the best model. The relationships of taxonomic and functional traits with environmental variables were examined by means of the biota environment (BIOENV) procedure (Clarke and Ainsworth, 1993), which calculates rank correlations between a similarity matrix derived from biological data and matrices derived from the environmental variables, thereby defining a set of variables that "best explain" the biotic structure. We performed RELATE and a stepwise distance-based linear model permutation test (DistLM; McArdle and Anderson, 2001) to identify which set of environmental variables predicted the multivariate variation in nematode species assemblages. The adjusted $R^{2}$ was used as a selection criterion to permit the fitting of the best explanatory environmental variables in the model. Euclidean distance was used as the resemblance measure in all DistLM procedures. Results were visualised with a distance-based redundancy analysis (dbRDA) (Anderson et al., 2008).

To identify the species that would characterise the three zones compared (shelf, slope, and basin), we performed the Indicator Species Analysis or IndVal (Dufrêne and Legendre, 1997) using multi-level pattern analysis (De Cáceres et al., 2010) in the R environment (R Development Core Team, 2015) with the "indicspecies" function. The statistical significance of the relationship between the species and site was tested by means of Monte Carlo randomisations with 1000 permutations. The details of the method are described by Dufrêne and Legendre (1997). All the analyses were performed with the procedures in the $\mathrm{R}$ software $(\mathrm{R}$ Development Core Team, 2015; Dimitriadou et al., 2011) and the PERMANOVA+ module of the PRIMER v6 software (Clarke and Gorley, 2006; Anderson et al., 2008). A schematic diagram was prepared from the taxonomic and functional data set that represented the pattern in the benthic zones of the western Indian continental margin. 


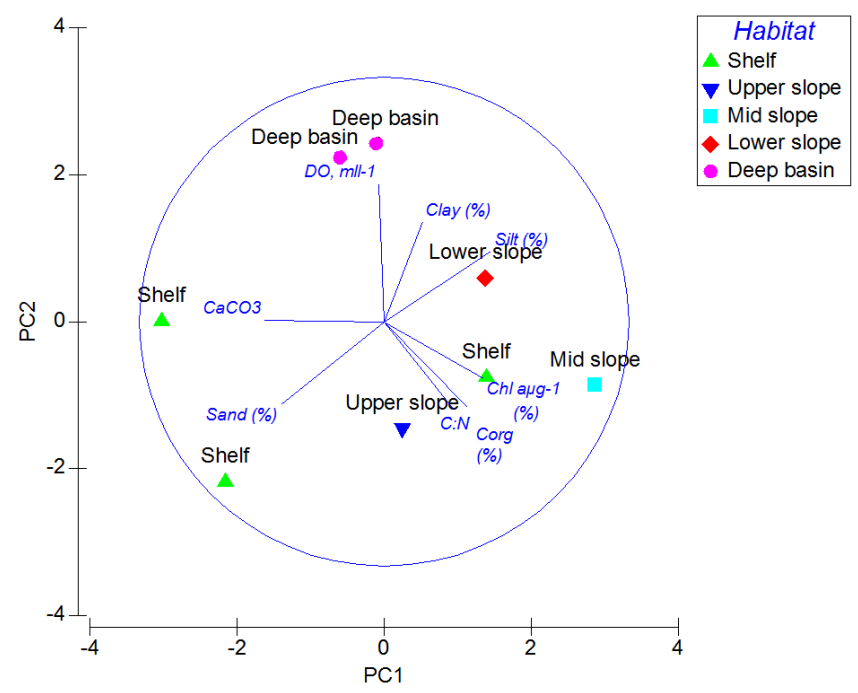

Figure 2. Principal-component analysis derived from the contribution of parameters in each benthic zone. PC 1 and 2 accounted for $81 \%$ of the total variation present.

\section{Results}

\subsection{Environmental parameters}

The sediment texture was variable, as the shelf region and upper slopes $(525 \mathrm{~m})$ were characterised by silty and sandy facies, whereas the sediments on the mid slope $(1001 \mathrm{~m})$, lower slope $(1524 \mathrm{~m})$, and in the basin were characterised by clayish silts. The salinity of the bottom water varied little, but temperature decreased with increasing depth. The bottom-water DO ranged from 0.08 to $2.3 \mathrm{~mL} \mathrm{~L}^{-1}$. The lowest near-bottom oxygen levels were recorded on the upper slope and mid slope $\left(0.08\right.$ and $0.28 \mathrm{mLL}^{-1}$, respectively), defined as the OMZ. Oxygen values began to increase at the lower slope. Higher values of DO were observed in the basin (Table 1). The core of the OMZ was located at $525 \mathrm{~m}$, where the lowest $\mathrm{DO}\left(0.08 \mathrm{mLL}^{-1}\right)$ value was recorded.

The OMZ was also characterised by higher values of sediment Chl $a$ and organic carbon (Table 1) than the shelf and basin were. A PCA ordination constructed from the eight environmental factors (DO, sediment chlorophyll, $\mathrm{C}_{\text {org }}$, $\mathrm{CaCO}_{3}, \mathrm{C}: \mathrm{N}$ ratio, clay, silt, and sand; Fig. 2) showed that the first two components accounted for about $81 \%$ of the variability in the data (PC1 explained $43.5 \%$, PC2 $33.3 \%$ ). Two shelf stations were characterised by high coarse-sand and $\mathrm{CaCO}_{3}$ content, whereas one (at a depth of $102 \mathrm{~m}$ ) clustered mainly with the slope stations, largely because of higher organic-matter content, and was clearly separated from the others on the basis of its higher silt content. Basin samples were characterised by a higher DO level (Fig. 2).

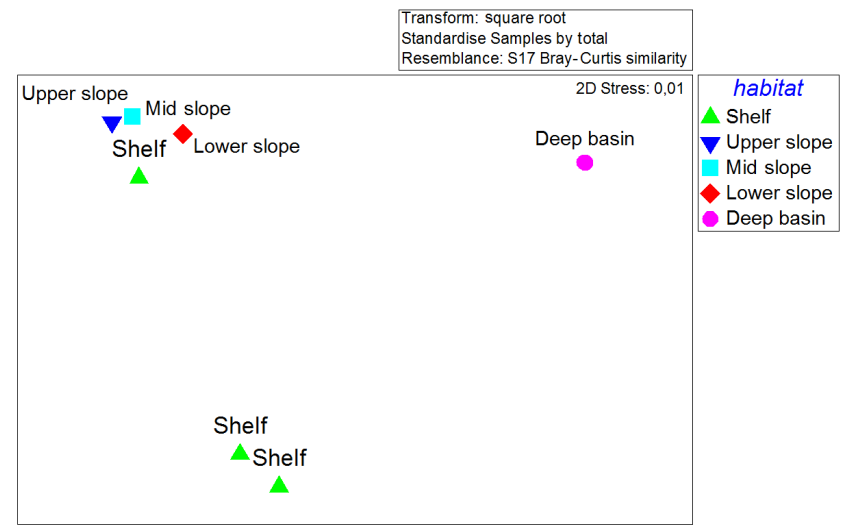

Figure 3. nMDS ordination based on nematode species abundance according to the Bray-Curtis similarity index.

\subsection{Nematode density and community structure}

A total of 110 nematode species belonging to 24 families were found along the transect. Nematode density was higher at the shelf stations than on the slope or in the basin. The lowest average density was observed in the basin: $62.9 \pm 2$ ind $10 \mathrm{~cm}^{-2}$. The mean nematode density in the slope region was $124.3 \pm 16$ ind $10 \mathrm{~cm}^{-2}$, and the lowest density was observed on the lower slope $\left(98.1\right.$ ind $10 \mathrm{~cm}^{-2}$ ), whereas the upper slope station near the shelf was represented by a density of 155.2 ind $10 \mathrm{~cm}^{-2}$, but the mid slope density was 120.0 ind $10 \mathrm{~cm}^{-2}$. The highest average nematode density $\left(176.6 \pm 37\right.$ ind $\left.10 \mathrm{~cm}^{-2}\right)$ was observed at shelf depth.

nMDS based on nematode species abundance (BrayCurtis) and presence or absence data illustrates clearly the extent to which the three zones differ (Figs. 3 and 4). The nMDS plot based on the Bray-Curtis similarity measure indicated three groups of samples (Fig. 3). The largest group included the slope stations and the deepest shelf station - those stations that form the OMZ. The PERMANOVA community results indicated significant differences between the three zones $(p=0.03)$, but the nMDS based on presence or absence separated only the slope and basin. The stations on the shelf were distributed randomly (Fig. 4), and the PERMANOVA community results confirmed nonsignificant differences between the zones $(p=0.12)$. In pairwise PERMANOVA, comparisons between shelf and deepbasin nematode assemblages differ significantly ( $p=0.046)$, whereas the pairwise comparisons between slope and shelf and between slope and basin were not significant (Table 2).

Thirty-eight species were identified that were found only in the shelf region. Of these, Chromadorita sp. 2 (2.78\%) and Sphaerolaimus gracilis $(2.21 \%)$ were dominant. Terschellingia Longicaudata (4.73\%) and Desmodora sp. 1 (4.42) dominated the slope, and Halalaimus sp. $1(1.11 \%)$ and Acantholaimus elegans $(1.11 \%)$ dominated the basin 
Table 1. Locations and depths of sampling stations and sediment texture.

\begin{tabular}{|c|c|c|c|c|c|c|c|c|}
\hline Depth (m) & 34 & 48 & 102 & 525 & 1001 & 1524 & 2001 & 2546 \\
\hline Lat $\left({ }^{\circ} \mathrm{N}\right)$ & $13^{\circ} 54.26^{\prime}$ & $13^{\circ} 59.88^{\prime}$ & $14^{\circ} 00.29^{\prime}$ & $14^{\circ} 00.24^{\prime}$ & $14^{\circ} 00.25^{\prime}$ & $14^{\circ} 00.30^{\prime}$ & $14^{\circ} 00.09^{\prime}$ & $13^{\circ} 59.55^{\prime}$ \\
\hline Long $\left({ }^{\circ} \mathrm{E}\right)$ & $74^{\circ} 18.97^{\prime}$ & $74^{\circ} 00.03^{\prime}$ & $73^{\circ} 29.94^{\prime}$ & $73^{\circ} 13.97^{\prime}$ & $73^{\circ} 08.11^{\prime}$ & $72^{\circ} 57.22^{\prime}$ & $71^{\circ} 13.21^{\prime}$ & $70^{\circ} 48.40^{\prime}$ \\
\hline Temperature, ${ }^{\circ} \mathrm{C}$ & 23.2 & 20.84 & 18 & 10.7 & 7.85 & 5 & - & - \\
\hline Salinity (psu) & 35.8 & 35.5 & 35.1 & 35.3 & 35.2 & 35 & - & - \\
\hline $\mathrm{DO}, \mathrm{mLL}^{-1}$ & 0.69 & 0.56 & 0.38 & 0.08 & 0.28 & 1.35 & 2.3 & 2.3 \\
\hline Sediment Chl- $a \mu \mathrm{g}^{-1}$ & 1.4 & 0.2 & 0.6 & 0.7 & 2.1 & 0.6 & 0.6 & 0.2 \\
\hline $\mathrm{C}_{\text {org }}(\%)$ & 1.9 & 0.8 & 1.5 & 3.8 & 4.4 & 2.2 & 0.3 & 0.9 \\
\hline $\mathrm{C}: \mathrm{N}$ & 11.0 & - & 10.3 & 10.8 & 8.9 & 8.2 & 4.6 & 4.9 \\
\hline Clay (\%) & 8.3 & 9.8 & 3.0 & 12.9 & 13.2 & 8.7 & 15.1 & 15.6 \\
\hline Silt $(\%)$ & 75.6 & 39.7 & 38.5 & 53.6 & 84.5 & 89.4 & 79.2 & 71.7 \\
\hline Sand (\%) & 16.0 & 50.5 & 58.5 & 33.5 & 2.3 & 1.9 & 5.7 & 12.7 \\
\hline Texture & Clayey silt & Silty sand & Silty sand & Sandy silt & Clayey silt & Clayey silt & Clayey silt & Clayey silt \\
\hline $\mathrm{CaCO}_{3}$ & 26.8 & 69.2 & 65.1 & 44.5 & 28.3 & 24.5 & 49.3 & 53.7 \\
\hline
\end{tabular}

Table 2. Results of pairwise comparison (samples from different zones) PERMANOVA analyses (based on Bray-Curtis similarity measure). Data were fourth-root transformed; resemblance was calculated according to Bray and Curtis. The values indicate differences significant at $p<0.05$. (Perm: permutation; MC: Monte Carlo randomisation.)

\begin{tabular}{llcccc}
\hline & Groups & $t$ & $\begin{array}{c}\mathrm{P} \\
\text { (perm) }\end{array}$ & $\begin{array}{c}\text { Unique } \\
\text { perms }\end{array}$ & $\begin{array}{c}\mathrm{P} \\
(\mathrm{MC})\end{array}$ \\
\hline Taxonomic & Shelf vs. slope & 1.7529 & 0.317 & 3 & 0.264 \\
& Shelf vs. deep basin & 3.3538 & 0.332 & 3 & 0.046 \\
& Slope vs. deep basin & 6.0733 & 0.352 & 3 & 0.067 \\
\hline $\begin{array}{l}\text { Functional } \\
\text { traits }\end{array}$ & Shelf vs. slope & 2.2523 & 0.346 & 3 & 0.181 \\
& & & & & \\
& Shelf vs. deep basin & 5.0419 & 0.354 & 3 & 0.013 \\
& Slope vs. deep basin & 18.508 & 0.342 & 3 & 0.028 \\
\hline
\end{tabular}

(Table 3). Across the entire study area, however, the dominant species were Terschellingia longicaudata, (15.2\%), Desmodora sp. 1 (14.5\%), Sphaerolaimus gracilis (11.7\%), and Theristus ensifer (9.1\%); their maximum contributions came from shelf stations.

Only seven species were found exclusively in the OMZ: Pselionema sp. 1, Choanolaimus sp. 2, Halichoanolaimus sp. 1, Cobbia dentata, Daptonema sp. 1, Trissonchulus sp. 1 , and Minolaimus sp. 1. Only nine species were found exclusively in the basin: Acantholaimus calathus, Acantholaimus mirabilis, Sphaerolaimus sp. 1, Subsphaerolaimus sp. 1, Pierrickia sp. 2, Sabatieria praedatrix, Epacanthion sp. 1, Longicyatholaimus sp. 1, and Oncholaimus attenuatus. The top 10 dominant species from OMZ and from the remaining areas are given in Table 4.

The IndVal index produced a list of indicator species for each group of sites: four genera were indicative of the shelf area and five genera of the slope (Table 5). Viscosia viscosia ( $p=0.005$; statistical value: 0.751$)$ was a good indicator of the shelf, whereas Choanolaimus sp. 2 was strongly

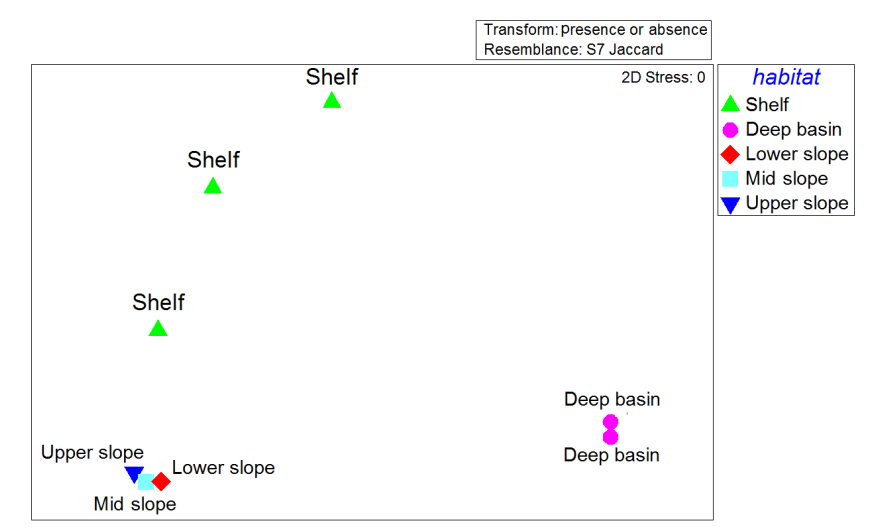

Figure 4. nMDS ordination based on nematode species presence or absence according to the Jaccard similarity index.

and significantly ( $p=0.005$; statistical value: 0.950$)$ associated with the slope. Acantholaimus mirabilis $(p=0.005$; statistical value: 1.000 ) was significantly associated with the basin. In addition, a number of indicator species were highly significantly $(p=0.005)$ associated with the shelf, slope, or basin. Table 5 lists which species were associated with which zones. The conditional probability or positive predictive value of the species and the conditional probability of finding the species at sites belonging to any of the zones are shown in Table 5 for the relevant species, but those species with the highest IndVal value for the set of all the samples from the three zones (e.g. Acantholaimus elegans, Acantholaimus filicaudatus, Anoplostoma blanchardi, Anoplostoma sp. 1, Synonchiella sp. 1, Desmoscolex sp. 1, Tricoma sp. 1, and Siphonolaimus ewensis) were not amenable to statistical testing because of the lack of an external group for comparison.

The three benthic zones differed significantly in the diversity indices (Margalef's index: $d$; Pielou's index: $J^{\prime}$, evenness; expected total number of species: ES (51); and $\log _{2}$ 
Table 3. Average relative abundances (\%) of the most abundant species belonging to each of three benthic zones. Only the top five dominant species from each zone are presented.

\begin{tabular}{lclclc}
\hline Species & Shelf $(\%)$ & Species & Slope $(\%)$ & Species & Basin (\%) \\
\hline Chromadorita sp. 2 & 2.78 & Terschellingia longicaudata & 4.73 & Halalaimus sp. 1 & 1.11 \\
Sphaerolaimus gracilis & 2.21 & Desmodora sp. 1 & 4.42 & Acantholaimus elegans & 1.11 \\
Setosabatieria sp. 1 & 2.06 & Theristus ensifer & 3.13 & Setosabatieria sp. 1 & 0.92 \\
Theristus heterospiculum & 1.98 & Sphaerolaimus gracilis & 2.36 & Anoplostoma sp. 1 & 0.72 \\
Synonchiella sp. 1 & 1.68 & Halichoanolaimus sp. 1 & 2.10 & Daptonema circulum & 0.53 \\
\hline
\end{tabular}

Table 4. The 10 most abundant species recorded from the oxygen minimum zone (OMZ) and from areas outside that zone.

\begin{tabular}{lclc}
\hline Species & OMZ $(\%)$ & Species & Outside OMZ (\%) \\
\hline Terschellingia longicaudata & 41.5 & Setosabatieria sp. 1 & 14.1 \\
Desmodora sp. 1 & 37.2 & Chromadorita sp. 2 & 11.2 \\
Sphaerolaimus gracilis & 27.6 & Sphaerolaimus gracilis & 8.9 \\
Theristus ensifer & 24.9 & Theristus heterospiculum & 8.3 \\
Halichoanolaimus sp. 1 & 15.3 & Synonchiella sp. 1 & 7.5 \\
Pterygonema sp. 1 & 14.2 & Metasphaerolaimus sp. 2 & 6.4 \\
Daptonema sp. 1 & 13.1 & Daptonema sp. 2 & 6.3 \\
Parasphaerolaimus sp. 1 & 12.1 & Siphonolaimus ewensis & 6.0 \\
Halichoanolaimus robustus & 11.5 & Axonolaimus sp. 3 & 5.8 \\
Trissonchulus sp. 1 & 11.5 & Parasphaerolaimus sp. 1 & 5.8 \\
\hline
\end{tabular}

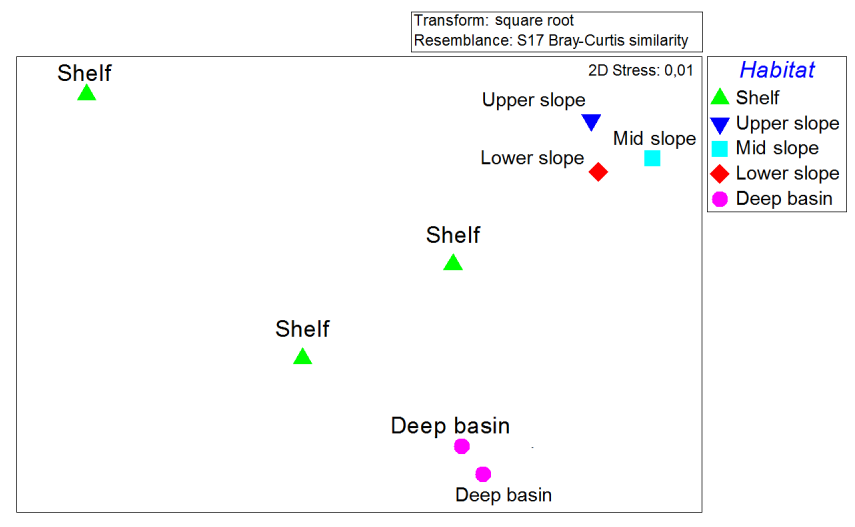

Figure 5. nMDS ordination based on nematode species' biological traits according to the Bray-Curtis similarity index.

Shannon-Wiener index for species diversity: $H^{\prime}$ ) of nematode assemblages (PERMANOVA: $p<0.05$ ). The average values of diversity indices in each zone are given in Table 6 .

\subsection{Functional Traits}

Functional attributes of nematode communities in the Arabian Sea are listed in Tables 7 and 8. The geographic separation was less pronounced in the ordinations derived from functional characteristics of nematode communities, although the basin and slope samples were clustered into groups, but shelf stations were randomly distributed (Fig. 5). As shown by the results of pairwise PERMANOVA, three
Table 5. List of indicator species calculated by IndVal index; number of genera associated with the shelf group: 4; number of genera associated with slope groups: 5 ; number of genera associated with the basin: 7 .

\begin{tabular}{|c|c|c|}
\hline & Association statistic & $P$ value \\
\hline \multicolumn{3}{|l|}{ Shelf } \\
\hline Viscosia viscosia & 0.978 & 0.005 \\
\hline Oxystomina affinis & 0.976 & 0.005 \\
\hline Aegialoalaimus sp. 1 & 0.973 & 0.005 \\
\hline Axonolaimus sp. 1 & 0.950 & 0.045 \\
\hline \multicolumn{3}{|l|}{ Slope } \\
\hline Choanolaimus sp. 2 & 1.000 & 0.005 \\
\hline Cobbia dentata & 0.973 & 0.041 \\
\hline Daptonema sp. 1 & 0.951 & 0.041 \\
\hline Halichoanolaimus sp. 1 & 0.942 & 0.042 \\
\hline Pselionema sp. 1 & 0.941 & 0.042 \\
\hline \multicolumn{3}{|l|}{ Basin } \\
\hline Acantholaimus mirabilis & 1.000 & 0.005 \\
\hline Acantholaimus calathus & 1.000 & 0.005 \\
\hline Sabatieria ornata & 1.000 & 0.005 \\
\hline Theristus heterospiculum & 1.000 & 0.040 \\
\hline Setosabatieria sp. 1 & 0.994 & 0.030 \\
\hline Metasphaerolaimus sp. 2 & 0.994 & 0.030 \\
\hline Dagda sp. 1 & 0.983 & 0.045 \\
\hline
\end{tabular}




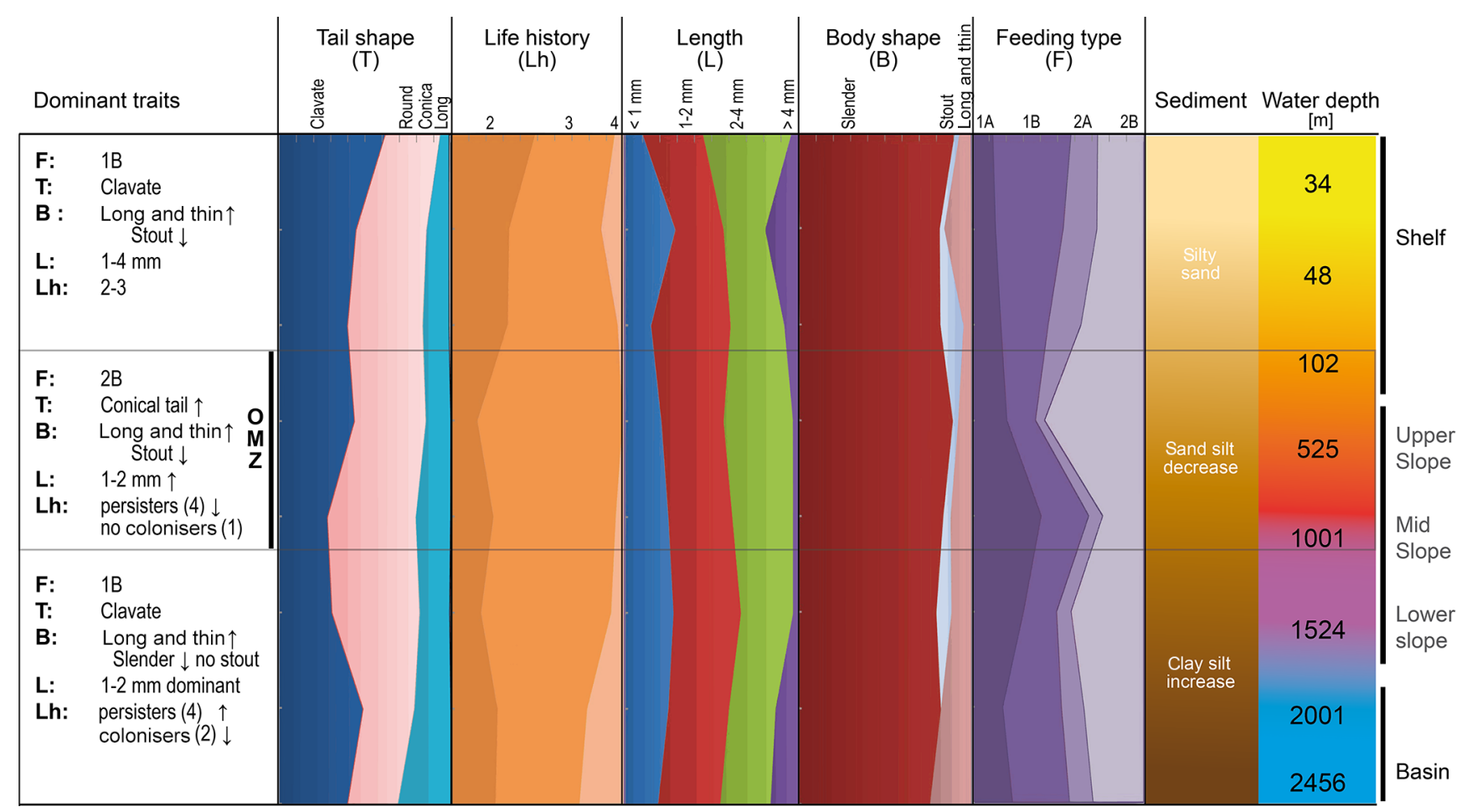

Figure 6. Schematic model of the functional traits in each benthic zone.

Table 6. Mean and standard error for diversity indices of the nematode communities at species level. $d$ : Margalef's index for species richness; $J^{\prime}$ : Pielou's index for species evenness; ES (51): expected total number of species; $H^{\prime}\left(\log _{e}\right)$ : $\log _{2}$ Shannon-Wiener index for species diversity.

\begin{tabular}{ccccc}
\hline Zone & $d$ & $J^{\prime}$ & $\mathrm{ES}(51)$ & $H^{\prime}\left(\log _{e}\right)$ \\
\hline Shelf & $13.53 \pm 1.53$ & $0.98 \pm 0.01$ & $40.54 \pm 2.57$ & $4.04 \pm 0.10$ \\
Slope & $7.89 \pm 0.51$ & $0.98 \pm 0.01$ & $31.69 \pm 1.24$ & $3.56 \pm 0.06$ \\
Basin & $7.49 \pm 0.11$ & $0.97 \pm 0.0$ & $28.16 \pm 0.22$ & $3.48 \pm 0.01$ \\
\hline
\end{tabular}

zones containing nematode assemblages (shelf vs. deep basin; slope vs. deep basin) differed significantly. Assemblages were dominated by deposit feeders (1B, 1A) followed by predators ( $2 \mathrm{~B})$, whereas proportions of epigrowth feeders (2A) were comparatively low (Table 7). The shelf area was dominated by non-selective deposit feeders (1B) and predators (2B), whereas the slope stations showed the highest proportions (29-48\%) of predators or omnivores (group 2B). Similarly, the dominance of predators (2B) was seen in OMZ stations from 102 to $1001 \mathrm{~m}$. The shelf and basin areas were dominated by deposit feeders (mainly the non-selective 1B group).

Clavate and conical were the most prevalent tail shapes at the majority of stations (Table 7); the average proportion of conical tails was higher on the slope and at the OMZ stations (33-49\%). Clavate tails dominated at all stations, but
Table 7. Functional trait matrix showing the percentages of all individuals belonging to four nematode feeding categories (1 A: no buccal cavity or a fine tubular one, selective deposit (bacterial) feeders; 1B: large but unarmed buccal cavity, non-selective deposit feeders; 2A: buccal cavity with scraping tooth or teeth, epigrowth (diatom) feeders; 2B: buccal cavity with large jaws, predators or omnivores) and four tail-shape categories.

\begin{tabular}{ccccccccc}
\hline \multicolumn{4}{c}{ Feeding habits } & \multicolumn{5}{c}{ Tail shapes } \\
\hline Depth & 1 A & $1 B$ & 2A & 2B & Clavate & Conical & Long & Round \\
\hline 34 & 12 & 46 & 15 & 27 & 62 & 32 & 5 & 1 \\
48 & 14 & 39 & 20 & 27 & 45 & 41 & 13 & 1 \\
102 & 17 & 28 & 19 & 36 & 40 & 44 & 15 & 1 \\
525 & 20 & 17 & 5 & 58 & 44 & 41 & 14 & 0 \\
1001 & 40 & 28 & 8 & 24 & 28 & 51 & 20 & 0 \\
1524 & 30 & 19 & 8 & 42 & 31 & 51 & 17 & 1 \\
2001 & 18 & 34 & 13 & 35 & 49 & 30 & 21 & 0 \\
2456 & 24 & 33 & 14 & 29 & 40 & 29 & 31 & 0 \\
\hline
\end{tabular}

slightly less on the slope and inside the OMZ (1001 m) than on the shelf and in the basin area. Average adult lengths of nematodes ranged from 1 to $4 \mathrm{~mm}$, and the majority of all recorded individuals occurred in the two intermediate length classes (1-2 and 2-4 mm). The OMZ stations showed the highest proportion of individuals from the $1-2 \mathrm{~mm}$ category (36-62\%); those from the $2-4 \mathrm{~mm}$ size category were the second most dominant (28-39\%). Moreover, the basin was also dominated by these two length categories. 
Table 8. Functional trait matrix showing the percentages of all individuals belonging to four body-length categories, three body-shape categories, and five life-history strategies (coloniser-persister score).

\begin{tabular}{ccccccccccccc}
\hline Depth & $<1 \mathrm{~mm}$ & $1-2 \mathrm{~mm}$ & $2-4 \mathrm{~mm}$ & $>4 \mathrm{~mm}$ & Slender & Stout & Long and thin & 1 & 2 & 3 & 4 & 5 \\
\hline 34 & 10 & 35 & 51 & 4 & 82 & 3 & 6 & 0 & 49 & 46 & 5 & 0 \\
48 & 29 & 28 & 24 & 19 & 76 & 2 & 14 & 0 & 34 & 53 & 13 & 0 \\
102 & 15 & 46 & 31 & 8 & 82 & 13 & 4 & 0 & 33 & 64 & 3 & 0 \\
525 & 21 & 36 & 40 & 3 & 89 & 3 & 7 & 0 & 15 & 84 & 1 & 0 \\
1001 & 25 & 37 & 35 & 3 & 83 & 4 & 12 & 0 & 24 & 71 & 5 & 0 \\
1524 & 28 & 39 & 30 & 3 & 80 & 9 & 11 & 0 & 17 & 76 & 7 & 0 \\
2001 & 25 & 35 & 27 & 13 & 83 & 0 & 17 & 0 & 27 & 52 & 21 & 0 \\
2546 & 19 & 36 & 29 & 16 & 76 & 0 & 24 & 0 & 26 & 49 & 26 & 0 \\
\hline
\end{tabular}

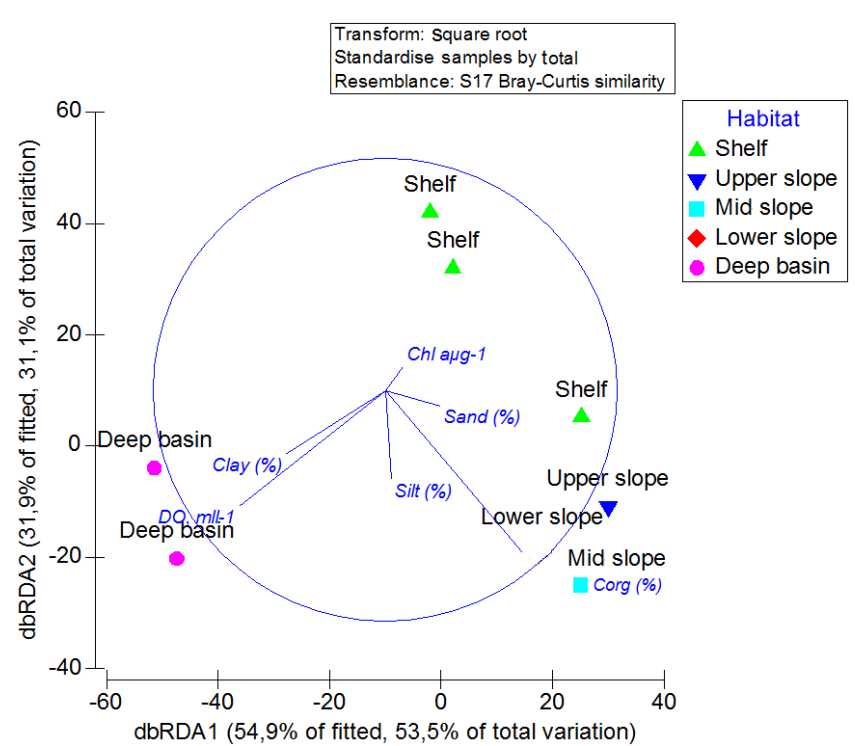

Figure 7. Distance-based redundancy (dbRDA) bubble plot illustrating the DistLM model based on the species assemblage data and fitted environmental variables with their vectors (strength and direction of effect of the variable on the ordination plot). Axis legends include percentage of variation explained by the fitted model and percentage of total variation explained by the axis.

The majority of the nematodes were slender, although their proportion decreased with depth (from $82 \%$ on the shelf to $76 \%$ in the basin), whereas stout animals accounted for between 2 and $13 \%$. Long and thin animals continuously decreased with increasing depth as far as the lower slope (at the core of OMZ), but they were more abundant (17-24\%) in the basin than those of slender or stout shape were. Over $76 \%$ of all identified individuals attained a C-P score of 2 to 3 . The shelf, slope, and basin regions mostly harboured colonisers in the range of 2-3. Extreme persisters (C-P score of 5) and extreme colonisers were completely absent (Table 8 ).

The information on a particular functional group was not a simple reflection of the species abundance data. Ecological information captured by adult length, adult shape, and

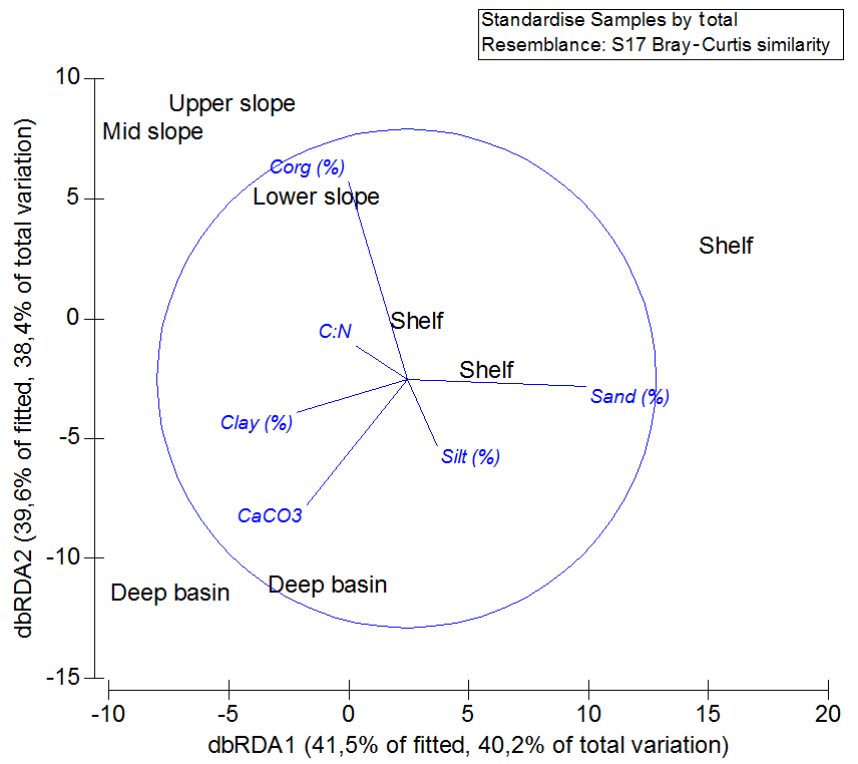

Figure 8. Distance-based redundancy (dbRDA) bubble plot illustrating the DistLM model based on the species functional assemblage data and fitted environmental variables with their vectors (strength and direction of effect of the variable on the ordination plot). Axis legends include percentage of variation explained by the fitted model and percentage of total variation explained by the axis.

life-history strategy was less site-specific and thus differed notably from information contained in taxonomic groups.

Moreover, the biological-trait matrix revealed no particular notable relationships between traits. Certain trends were observed, however; for example, 1-2 and 2-4 mm lengths were generally correlated with slender animals and with colonisers (C-P score 2-3), whereas nematodes with a length $>4 \mathrm{~mm}$ had higher $\mathrm{C}-\mathrm{P}$ scores and a long and thin body shape. Some other combinations occurred, such as nonselective feeders with clavate tail shape, whereas predators followed a trend similar to that of the conical tail-shape category (Table 9).

The schematic model represents the exact trend of each functional trait at each benthic zone. The relative abundance 
Table 9. Biological-trait matrix along with contribution (\%) of species at each zone.

\begin{tabular}{|c|c|c|c|c|c|c|c|c|c|c|c|c|c|c|c|c|c|c|c|c|c|}
\hline \multirow[b]{2}{*}{ Species } & \multicolumn{3}{|c|}{ Zones } & $\mathrm{Buc}$ & $\mathrm{cal} \mathrm{m}$ & orpho & & & Tail & shape & & & lult len & th $(\mathrm{m}$ & & & ult sh & & & $\mathrm{e} \mathrm{hi}$ & -P score) \\
\hline & Shelf $(\%)$ & Slope $(\%)$ & $\operatorname{Basin}(\%)$ & $1 \mathrm{~A}$ & 1B & $2 \mathrm{~A}$ & $2 \mathrm{~B}$ & $\mathrm{R}$ & $\mathrm{E} / \mathrm{F}$ & $\mathrm{CO}$ & $\mathrm{CA}$ & $>1$ & $1-2$ & $2-4$ & $>4$ & ST & SL & $\mathrm{L} / \mathrm{T}$ & 2 & 3 & 4 \\
\hline Acantholaimus calathus & 0.11 & 0.00 & 0.00 & 0 & 0 & 1 & 0 & 0 & 1 & 0 & 0 & 0 & 1 & 0 & 0 & 0 & 1 & 0 & 0 & 1 & 0 \\
\hline Acantholaimus elegans & 0.19 & 0.23 & 1.11 & 0 & 0 & 1 & 0 & 0 & 0 & 1 & 0 & 0 & 1 & 0 & 0 & 0 & 1 & 0 & 0 & 1 & 0 \\
\hline Acantholaimus filicaudatus & 0.15 & 0.15 & 0.19 & 0 & 0 & 1 & 0 & 0 & 0 & 1 & 0 & 0 & 1 & 0 & 0 & 0 & 1 & 0 & 0 & 1 & 0 \\
\hline Acantholaimus mirabilis & 0.31 & 0.00 & 0.00 & 0 & 0 & 1 & 0 & 0 & 0 & 1 & 0 & 1 & 0 & 0 & 0 & 0 & 1 & 0 & 0 & 1 & 0 \\
\hline Actarjania sp. 1 & 0.15 & 0.00 & 0.00 & 0 & 1 & 0 & 0 & 0 & 0 & 0 & 1 & 0 & 1 & 0 & 0 & 0 & 1 & 0 & 1 & 0 & 0 \\
\hline Actinonema sp. 1 & 0.31 & 0.00 & 0.00 & 0 & 0 & 1 & 0 & 0 & 0 & 1 & 0 & 0 & 1 & 0 & 0 & 0 & 1 & 0 & 0 & 1 & 0 \\
\hline Actinonema sp. 2 & 0.15 & 0.00 & 0.00 & 0 & 0 & 1 & 0 & 0 & 0 & 1 & 0 & 0 & 1 & 0 & 0 & 0 & 1 & 0 & 0 & 1 & 0 \\
\hline Actinonema sp. 3 & 0.31 & 0.00 & 0.00 & 0 & 0 & 1 & 0 & 0 & 0 & 1 & 0 & 0 & 1 & 0 & 0 & 0 & 1 & 0 & 0 & 1 & 0 \\
\hline Aegialoalaimus sp. 1 & 0.38 & 0.00 & 0.00 & 1 & 0 & 0 & 0 & 0 & 0 & 1 & 0 & 0 & 1 & 0 & 0 & 0 & 1 & 0 & 0 & 0 & 1 \\
\hline Anoplostoma blanchardi & 0.69 & 0.69 & 0.50 & 0 & 1 & 0 & 0 & 0 & 0 & 1 & 0 & 0 & 1 & 0 & 0 & 0 & 1 & 0 & 0 & 1 & 0 \\
\hline Anoplostoma sp. 1 & 0.50 & 0.19 & 0.72 & 0 & 1 & 0 & 0 & 0 & 0 & 1 & 0 & 0 & 0 & 1 & 0 & 0 & 1 & 0 & 0 & 1 & 0 \\
\hline Anoplostoma sp. 2 & 0.38 & 0.38 & 0.00 & 0 & 1 & 0 & 0 & 0 & 0 & 1 & 0 & 0 & 1 & 0 & 0 & 0 & 1 & 0 & 0 & 1 & 0 \\
\hline Araeolaimus sp. 1 & 0.19 & 0.04 & 0.00 & 1 & 0 & 0 & 0 & 0 & 0 & 1 & 0 & 0 & 1 & 0 & 0 & 0 & 1 & 0 & 0 & 1 & 0 \\
\hline Araeolaimus sp. 2 & 0.23 & 0.00 & 0.27 & 1 & 0 & 0 & 0 & 0 & 0 & 1 & 1 & 0 & 1 & 0 & 0 & 0 & 1 & 0 & 0 & 1 & 0 \\
\hline Axonolaimus sp. 1 & 1.03 & 0.00 & 0.00 & 0 & 1 & 0 & 0 & 0 & 0 & 1 & 0 & 0 & 1 & 0 & 0 & 0 & 1 & 0 & 1 & 0 & 0 \\
\hline Axonolaimus sp. 2 & 0.15 & 0.04 & 0.00 & 0 & 1 & 0 & 0 & 0 & 0 & 0 & 0 & 0 & 1 & 0 & 0 & 0 & 1 & 0 & 1 & 0 & 0 \\
\hline Axonolaimus sp. 3 & 1.45 & 0.00 & 0.00 & 0 & 1 & 0 & 0 & 0 & 0 & 0 & 1 & 0 & 0 & 1 & 0 & 0 & 1 & 0 & 1 & 0 & 0 \\
\hline Bathyeurystomina sp. 1 & 0.11 & 0.00 & 0.38 & 0 & 0 & 0 & 1 & 0 & 0 & 1 & 0 & 0 & 0 & 0 & 1 & 0 & 1 & 0 & 0 & 0 & 1 \\
\hline Campylaimus sp. 1 & 0.19 & 0.00 & 0.00 & 0 & 1 & 0 & 0 & 0 & 0 & 0 & 1 & 0 & 1 & 0 & 0 & 0 & 1 & 0 & 0 & 1 & 0 \\
\hline Ceramonema yunfengi & 0.46 & 0.00 & 0.00 & 1 & 0 & 0 & 0 & 0 & 0 & 1 & 0 & 0 & 1 & 0 & 0 & 0 & 1 & 0 & 0 & 1 & 0 \\
\hline Ceramonema attenuatum & 0.23 & 0.04 & 0.00 & 1 & 0 & 0 & 0 & 0 & 0 & 1 & 0 & 0 & 1 & 0 & 0 & 0 & 1 & 0 & 0 & 1 & 0 \\
\hline Cheironchus sp. 1 & 0.23 & 0.00 & 0.00 & 0 & 0 & 0 & 1 & 1 & 0 & 0 & 0 & 0 & 0 & 1 & 0 & 0 & 1 & 0 & 0 & 1 & 0 \\
\hline Choanolaimus sp. 2 & 0.04 & 0.38 & 0.00 & 0 & 0 & 0 & 1 & 0 & 0 & 1 & 0 & 0 & 0 & 1 & 0 & 0 & 1 & 0 & 0 & 1 & 0 \\
\hline Chromadora sp. 1 & 0.23 & 0.34 & 0.00 & 0 & 0 & 1 & 0 & 0 & 0 & 0 & 1 & 1 & 0 & 0 & 0 & 0 & 1 & 0 & 0 & 1 & 0 \\
\hline Chromadorita sp. 1 & 0.19 & 0.65 & 0.00 & 0 & 0 & 1 & 0 & 0 & 0 & 1 & 0 & 1 & 0 & 0 & 0 & 1 & 0 & 0 & 0 & 1 & 0 \\
\hline Chromadorita sp. 2 & 2.78 & 0.19 & 0.00 & 0 & 0 & 1 & 0 & 0 & 0 & 1 & 0 & 0 & 1 & 0 & 0 & 0 & 1 & 0 & 0 & 1 & 0 \\
\hline Cobbia dentata & 0.72 & 0.38 & 0.00 & 0 & 0 & 1 & 0 & 0 & 1 & 0 & 0 & 0 & 1 & 0 & 0 & 0 & 1 & 0 & 0 & 1 & 0 \\
\hline Cobbia sp. 1 & 0.34 & 0.00 & 0.00 & 0 & 0 & 1 & 0 & 0 & 1 & 0 & 0 & 0 & 1 & 0 & 0 & 0 & 1 & 0 & 0 & 1 & 0 \\
\hline Cobbia sp. 3 & 0.72 & 0.04 & 0.04 & 0 & 0 & 1 & 0 & 0 & 1 & 0 & 0 & 0 & 1 & 0 & 0 & 0 & 1 & 0 & 0 & 1 & 0 \\
\hline Cobbia sp. 2 & 0.23 & 0.11 & 0.00 & 0 & 0 & 1 & 0 & 0 & 0 & 1 & 0 & 0 & 1 & 0 & 0 & 0 & 1 & 0 & 0 & 1 & 0 \\
\hline Dagda sp. 1 & 0.31 & 0.00 & 0.27 & 0 & 0 & 1 & 0 & 0 & 0 & 1 & 0 & 0 & 0 & 1 & 0 & 0 & 1 & 0 & 0 & 1 & 0 \\
\hline Daptonema circulum & 0.84 & 0.31 & 0.53 & 0 & 1 & 0 & 0 & 0 & 0 & 0 & 1 & 0 & 0 & 1 & 0 & 0 & 1 & 0 & 1 & 0 & 0 \\
\hline Daptonema sp. 1 & 0.72 & 1.14 & 0.00 & 0 & 1 & 0 & 0 & 0 & 0 & 0 & 1 & 1 & 0 & 0 & 0 & 1 & 0 & 0 & 1 & 0 & 0 \\
\hline Daptonema sp. 2 & 1.56 & 0.00 & 0.00 & 0 & 1 & 0 & 0 & 0 & 0 & 0 & 1 & 0 & 1 & 0 & 0 & 0 & 1 & 0 & 1 & 0 & 0 \\
\hline Desmodora sp. 1 & 0.88 & 4.42 & 0.38 & 0 & 0 & 1 & 0 & 0 & 0 & 1 & 0 & 0 & 1 & 0 & 0 & 1 & 0 & 0 & 1 & 0 & 0 \\
\hline Desmoscolex sp. 1 & 1.30 & 0.00 & 0.00 & 1 & 0 & 0 & 0 & 0 & 0 & 1 & 0 & 1 & 0 & 0 & 0 & 1 & 0 & 0 & 0 & 0 & 1 \\
\hline Diplolaimella sp. 1 & 0.11 & 0.00 & 0.00 & 0 & 1 & 0 & 0 & 0 & 1 & 0 & 0 & 1 & 0 & 0 & 0 & 0 & 1 & 0 & 1 & 0 & 0 \\
\hline Diplolaimelloides sp. 1 & 0.04 & 0.04 & 0.00 & 0 & 1 & 0 & 0 & 0 & 1 & 0 & 0 & 1 & 0 & 0 & 0 & 0 & 0 & 0 & 1 & 0 & 0 \\
\hline Dolicholaimus sp. 1 & 0.50 & 0.00 & 0.00 & 0 & 0 & 0 & 1 & 0 & 0 & 0 & 1 & 0 & 0 & 1 & 0 & 0 & 1 & 0 & 1 & 0 & 0 \\
\hline Doliolaimus sp. 1 & 0.00 & 0.00 & 0.11 & 0 & 0 & 0 & 1 & 0 & 0 & 1 & 0 & 0 & 1 & 0 & 0 & 0 & 0 & 0 & 0 & 1 & 0 \\
\hline Dorylaimopsis sp. 1 & 0.15 & 0.00 & 0.00 & 0 & 0 & 1 & 0 & 0 & 0 & 0 & 1 & 0 & 1 & 0 & 0 & 0 & 1 & 0 & 1 & 0 & 0 \\
\hline Dorylaimopsis sp. 2 & 0.15 & 0.46 & 0.00 & 0 & 0 & 1 & 0 & 0 & 0 & 0 & 1 & 0 & 1 & 0 & 0 & 0 & 1 & 0 & 1 & 0 & 0 \\
\hline Epacanthion sp. 1 & 0.00 & 0.00 & 0.31 & 0 & 0 & 0 & 1 & 0 & 0 & 0 & 1 & 0 & 0 & 0 & 1 & 0 & 1 & 0 & 0 & 1 & 0 \\
\hline Gammanema sp. 1 & 0.08 & 0.00 & 0.00 & 0 & 0 & 0 & 1 & 0 & 0 & 1 & 0 & 0 & 0 & 1 & 0 & 0 & 1 & 0 & 0 & 1 & 0 \\
\hline Halalaimus gracilis & 0.38 & 0.00 & 0.08 & 1 & 0 & 0 & 0 & 0 & 1 & 0 & 0 & 0 & 1 & 0 & 0 & 0 & 1 & 0 & 0 & 0 & 1 \\
\hline Halalaimus sp. 1 & 0.00 & 0.50 & 1.11 & 1 & 0 & 0 & 0 & 0 & 1 & 0 & 0 & 0 & 0 & 1 & 0 & 0 & 0 & 1 & 0 & 0 & 1 \\
\hline Halalaimus sp. 2 & 0.00 & 0.23 & 0.53 & 1 & 0 & 0 & 0 & 0 & 1 & 0 & 0 & 0 & 0 & 1 & 0 & 0 & 0 & 1 & 0 & 0 & 1 \\
\hline Halalaimus sp. 2 & 0.00 & 0.19 & 0.42 & 1 & 0 & 0 & 0 & 0 & 1 & 0 & 0 & 0 & 1 & 0 & 0 & 0 & 0 & 1 & 0 & 0 & 1 \\
\hline Halanonchus sp. 1 & 0.23 & 0.00 & 0.00 & 0 & 1 & 0 & 0 & 0 & 1 & 0 & 0 & 0 & 0 & 1 & 0 & 0 & 0 & 0 & 0 & 0 & 1 \\
\hline Halichoanolaimus chordiurus & 0.00 & 0.00 & 0.11 & 0 & 0 & 0 & 1 & 0 & 0 & 0 & 1 & 0 & 0 & 0 & 1 & 0 & 1 & 0 & 0 & 1 & 0 \\
\hline Halichoanolaimus robustus & 0.95 & 1.60 & 0.00 & 0 & 0 & 0 & 1 & 0 & 0 & 0 & 1 & 0 & 0 & 1 & 0 & 0 & 1 & 0 & 0 & 1 & 0 \\
\hline Halichoanolaimus sp. 1 & 0.08 & 2.10 & 0.00 & 0 & 0 & 0 & 1 & 0 & 0 & 0 & 1 & 0 & 0 & 1 & 0 & 0 & 1 & 0 & 0 & 1 & 0 \\
\hline Halichoanolaimus sp. 2 & 0.11 & 0.00 & 0.00 & 0 & 0 & 0 & 1 & 0 & 0 & 0 & 1 & 0 & 1 & 0 & 0 & 0 & 1 & 0 & 0 & 1 & 0 \\
\hline Hopperia sp. 1 & 0.95 & 0.00 & 0.00 & 0 & 0 & 0 & 1 & 0 & 1 & 0 & 0 & 0 & 0 & 1 & 0 & 0 & 1 & 0 & 1 & 0 & 0 \\
\hline Longicyatholaimus sp. 1 & 0.00 & 0.00 & 0.50 & 0 & 0 & 1 & 0 & 0 & 1 & 0 & 0 & 0 & 0 & 1 & 0 & 0 & 1 & 0 & 0 & 1 & 0 \\
\hline Marylynnia sp. 1 & 0.23 & 0.00 & 0.00 & 0 & 0 & 1 & 0 & 0 & 1 & 0 & 0 & 0 & 0 & 1 & 0 & 0 & 1 & 0 & 0 & 1 & 0 \\
\hline Mesacanthion sp. 1 & 0.19 & 0.00 & 0.00 & 0 & 0 & 0 & 1 & 0 & & 0 & 1 & 0 & 0 & & 1 & 0 & 1 & 0 & 0 & 1 & 0 \\
\hline Metalinhomoeus longiseta & 0.08 & 0.00 & 0.50 & 0 & 1 & 0 & 0 & 0 & 1 & 0 & 0 & 0 & 0 & 1 & 0 & 0 & 1 & 0 & 1 & 0 & 0 \\
\hline Metalinhomoeus sp. 1 & 0.19 & 0.00 & 0.00 & 0 & 1 & 0 & 0 & 0 & 1 & 0 & 0 & 0 & 0 & 1 & 0 & 0 & 1 & 0 & 1 & 0 & 0 \\
\hline Metasphaerolaimus sp. 1 & 0.00 & 0.00 & 0.38 & 0 & 0 & 0 & 1 & 0 & 0 & 0 & 1 & 0 & 1 & 0 & 0 & 0 & 1 & 0 & 0 & 1 & 0 \\
\hline Metasphaerolaimus sp. 2 & 1.33 & 0.04 & 0.27 & 0 & 0 & 0 & 1 & 0 & 0 & 0 & 1 & 0 & 1 & 0 & 0 & 0 & 1 & 0 & 0 & 1 & 0 \\
\hline Meyersia minor & 0.08 & 0.00 & 0.00 & 0 & 0 & 0 & 1 & 0 & 0 & 0 & 1 & 0 & 0 & 0 & 1 & 0 & 0 & 0 & 0 & 1 & 0 \\
\hline Meyersia sp. 1 & 0.23 & 0.15 & 0.23 & 0 & 0 & 0 & 1 & 0 & 0 & 0 & 1 & 0 & 0 & 0 & 1 & 0 & 0 & 0 & 0 & 1 & 0 \\
\hline Meyersia sp. 2 & 0.46 & 0.00 & 0.00 & 0 & 0 & 0 & 1 & 0 & 0 & 0 & 1 & 0 & 0 & 0 & 1 & 0 & 0 & 0 & 0 & 1 & 0 \\
\hline Microlaimus sp. 1 & 0.15 & 0.00 & 0.08 & 0 & 0 & 1 & 0 & 0 & 0 & 1 & 0 & 0 & 1 & 0 & 0 & 0 & 1 & 0 & 1 & 0 & 0 \\
\hline Minolaimus sp. 1 & 0.04 & 0.00 & 0.00 & 1 & 0 & 0 & 0 & 0 & 1 & 0 & 0 & 0 & 1 & 0 & 0 & 0 & 1 & 0 & 0 & 1 & 0 \\
\hline Oncholaimus attenuatus & 0.00 & 0.00 & 0.34 & 0 & 0 & 0 & 1 & 0 & 0 & 0 & 1 & 0 & 0 & 1 & 0 & 0 & 1 & 0 & 0 & 0 & 1 \\
\hline Oncholaimellus mediterraneus & 0.11 & 0.00 & 0.00 & 0 & 0 & 0 & 1 & 0 & 0 & 0 & 1 & 0 & 0 & 0 & 1 & 0 & 1 & 0 & 0 & 0 & 1 \\
\hline Oxystomina affinis & 0.42 & 0.00 & 0.00 & 1 & 0 & 0 & 0 & 0 & 0 & 0 & 1 & 0 & 1 & 0 & 1 & 0 & 1 & 0 & 0 & 0 & 1 \\
\hline Oxystomina sp. 1 & 0.61 & 0.08 & 0.00 & 1 & 0 & 0 & 0 & 0 & 0 & 0 & 1 & 0 & 1 & 0 & 0 & 0 & 0 & 1 & 0 & 0 & 1 \\
\hline Paralinhomoeus filiformis & 0.11 & 0.08 & 0.00 & 0 & 1 & 0 & 0 & 0 & 0 & 0 & 1 & 0 & 0 & 1 & 0 & 0 & 1 & 0 & 1 & 0 & 0 \\
\hline
\end{tabular}


Table 9. Continued.

\begin{tabular}{|c|c|c|c|c|c|c|c|c|c|c|c|c|c|c|c|c|c|c|c|c|c|}
\hline \multirow[b]{2}{*}{ Species } & \multicolumn{3}{|c|}{ Zones } & \multicolumn{4}{|c|}{ Buccal morphology } & \multicolumn{4}{|c|}{ Tail shape } & \multicolumn{4}{|c|}{ Adult Length (mm) } & \multicolumn{3}{|c|}{ Adult shape } & \multicolumn{3}{|c|}{ Life history (C-P score) } \\
\hline & Shelf $(\%)$ & Slope $(\%)$ & $\operatorname{Basin}(\%)$ & $1 \mathrm{~A}$ & 1B & $2 \mathrm{~A}$ & $2 \mathrm{~B}$ & $\mathrm{R}$ & $\mathrm{E} / \mathrm{F}$ & $\mathrm{CO}$ & $\mathrm{CA}$ & $>1$ & $1-2$ & $2-4$ & $>4$ & ST & SL & $\mathrm{L} / \mathrm{T}$ & 2 & 3 & 4 \\
\hline Paralinhomoeus lepturus & 0.34 & 0.84 & 0.00 & 0 & 1 & 0 & 0 & 0 & 0 & 0 & 1 & 0 & 0 & 0 & 1 & 0 & 0 & 1 & 1 & 0 & 0 \\
\hline Paralinhomoeus sp. 1 & 0.57 & 0.76 & 0.00 & 0 & 1 & 0 & 0 & 0 & 0 & 0 & 1 & 0 & 0 & 1 & 0 & 0 & 1 & 0 & 1 & 0 & 0 \\
\hline Paralinhomoeus sp. 2 & 0.42 & 0.00 & 0.08 & 0 & 1 & 0 & 0 & 0 & 0 & 0 & 1 & 0 & 0 & 0 & 1 & 0 & 0 & 1 & 1 & 0 & 0 \\
\hline Parasphaerolaimus sp. 1 & 1.45 & 0.92 & 0.00 & 0 & 0 & 0 & 1 & 0 & 0 & 0 & 1 & 0 & 0 & 1 & 0 & 0 & 1 & 0 & 0 & 1 & 0 \\
\hline Pierrickia sp. 1 & 0.23 & 0.00 & 0.00 & 1 & 0 & 0 & 0 & 0 & 0 & 0 & 1 & 0 & 1 & 0 & 0 & 0 & 0 & 0 & 1 & 0 & 0 \\
\hline Pierrickia sp. 2 & 0.00 & 0.00 & 0.11 & 1 & 0 & 0 & 0 & 0 & 0 & 0 & 1 & 0 & 1 & 0 & 0 & 0 & 0 & 0 & 1 & 0 & 0 \\
\hline Prooncholaimus sp. 1 & 0.69 & 0.00 & 0.00 & 0 & 0 & 0 & 1 & 0 & 0 & 1 & 0 & 0 & 0 & 1 & 0 & 0 & 0 & 0 & 0 & 0 & 1 \\
\hline Pselionema hexalatum & 0.46 & 1.26 & 0.00 & 1 & 0 & 0 & 0 & 0 & 0 & 1 & 0 & 1 & 0 & 0 & 0 & 0 & 0 & 0 & 0 & 1 & 0 \\
\hline Pselionema sp. 1 & 0.11 & 1.11 & 0.00 & 1 & 0 & 0 & 0 & 0 & 0 & 1 & 0 & 0 & 1 & 0 & 0 & 0 & 0 & 0 & 0 & 1 & 0 \\
\hline Pterygonema platti & 0.19 & 0.00 & 0.00 & 1 & 0 & 0 & 0 & 0 & 0 & 1 & 0 & 1 & 0 & 0 & 0 & 0 & 1 & 0 & 0 & 1 & 0 \\
\hline Pterygonema sp. 1 & 0.34 & 1.83 & 0.00 & 1 & 0 & 0 & 0 & 0 & 0 & 1 & 0 & 1 & 0 & 0 & 0 & 0 & 1 & 0 & 0 & 1 & 0 \\
\hline Richtersia sp. 1 & 0.23 & 0.00 & 0.00 & 0 & 1 & 0 & 0 & 0 & 0 & 1 & 0 & 1 & 0 & 0 & 0 & 1 & & 0 & 0 & 1 & 0 \\
\hline Sabatieria ornata & 0.65 & 0.00 & 0.11 & 0 & 1 & 0 & 0 & 0 & 0 & 0 & 1 & 0 & 0 & 1 & 0 & & 1 & 0 & 1 & 0 & 0 \\
\hline Sabatieria praedatrix & 0.00 & 0.00 & 0.11 & 0 & 1 & 0 & 0 & 0 & 0 & 0 & 1 & 0 & 1 & 0 & 0 & 0 & 1 & 0 & 1 & 0 & 0 \\
\hline Sabatieria pulchra & 0.50 & 0.00 & 0.00 & 0 & 1 & 0 & 0 & 0 & 0 & 0 & 1 & 0 & 1 & 0 & 0 & 0 & 1 & 0 & 1 & 0 & 0 \\
\hline Sabatieria punctata & 0.42 & 0.00 & 0.00 & 0 & 1 & 0 & 0 & 0 & 0 & 0 & 1 & 0 & 1 & 0 & 0 & 0 & 1 & 0 & 1 & 0 & 0 \\
\hline Sabatieria sp. 1 & 0.88 & 0.00 & 0.00 & 0 & 1 & 0 & 0 & 0 & 0 & 0 & 1 & 0 & 1 & 0 & 0 & 0 & 0 & 1 & 1 & 0 & 0 \\
\hline Sabatieria sp. 2 & 0.42 & 0.00 & 0.00 & 0 & 1 & 0 & 0 & 0 & 0 & 0 & 1 & 0 & 1 & 0 & 0 & 0 & 1 & 0 & 1 & 0 & 0 \\
\hline Sabatieria sp. 3 & 1.41 & 0.00 & 0.00 & 0 & 1 & 0 & 0 & 0 & 0 & 0 & 1 & 0 & 1 & 0 & 0 & 0 & 1 & 0 & 1 & 0 & 0 \\
\hline Setosabatieria sp. 1 & 2.06 & 0.00 & 0.92 & 0 & 1 & 0 & 0 & 0 & 0 & 0 & 1 & 0 & 1 & 0 & 0 & 0 & 1 & 0 & 1 & 0 & 0 \\
\hline Siphonolaimus ewensis & 1.11 & 0.88 & 0.38 & 0 & 0 & 0 & 1 & 0 & 0 & 1 & 0 & 0 & 0 & 0 & 1 & 0 & 0 & 1 & 0 & 1 & 0 \\
\hline Southerniella sp. 1 & 1.14 & 0.38 & 0.00 & 1 & 0 & 0 & 0 & 0 & 0 & 0 & 1 & 0 & 1 & 0 & 0 & 0 & 0 & 0 & 0 & 1 & 0 \\
\hline Sphaerolaimus balticus & 0.15 & 0.00 & 0.00 & 0 & 0 & 0 & 1 & 0 & 0 & 0 & 1 & 0 & 1 & 0 & 0 & 0 & 1 & 0 & 0 & 1 & 0 \\
\hline Sphaerolaimus gracilis & 2.21 & 2.36 & 0.00 & 0 & 0 & 0 & 1 & 0 & 0 & 0 & 1 & 0 & 1 & 0 & 0 & 0 & 1 & 0 & 0 & 1 & 0 \\
\hline Sphaerolaimus sp. 1 & 0.00 & 0.00 & 0.42 & 0 & 0 & 0 & 1 & 0 & 0 & 0 & 1 & 0 & 1 & 0 & 0 & 0 & 1 & 0 & 0 & 1 & 0 \\
\hline Subsphaerolaimus sp. 1 & 0.00 & 0.00 & 0.08 & 0 & 0 & 0 & 1 & 0 & 0 & 0 & 1 & 0 & 1 & 0 & 0 & 0 & 1 & 0 & 0 & 1 & 0 \\
\hline Synonchiella sp. 1 & 1.68 & 0.34 & 0.19 & 0 & 0 & 0 & 1 & 0 & 0 & 0 & 1 & 0 & 0 & 1 & 0 & 0 & 1 & 0 & 0 & 1 & 0 \\
\hline Terschellingia longicaudata & 1.18 & 4.73 & 0.04 & 1 & 0 & 0 & 0 & 0 & 1 & 0 & 0 & 0 & 1 & 0 & 0 & 0 & 1 & 0 & 0 & 1 & 0 \\
\hline Theristus ensifer & 0.42 & 3.13 & 0.04 & 0 & 1 & 0 & 0 & 0 & 0 & 1 & 0 & 0 & 1 & 0 & 0 & 0 & 1 & 0 & 1 & 0 & 0 \\
\hline Theristus heterospiculum & 1.98 & 0.00 & 0.08 & 0 & 1 & 0 & 0 & 0 & 0 & 1 & 0 & 0 & 1 & 0 & 0 & 0 & 1 & 0 & 1 & 0 & 0 \\
\hline Theristus interstitialis & 0.92 & 0.00 & 0.00 & 0 & 1 & 0 & 0 & 0 & 0 & 1 & 0 & 0 & 1 & 0 & 0 & 0 & 1 & 0 & 1 & 0 & 0 \\
\hline Tricoma sp. 1 & 0.19 & 0.00 & 0.00 & 1 & 0 & 0 & 0 & 0 & 0 & 1 & 0 & 1 & 0 & 0 & 0 & 1 & 0 & 0 & 0 & 0 & 1 \\
\hline Trissonchulus sp. 1 & 0.46 & 1.18 & 0.00 & 0 & 0 & 0 & 1 & 0 & 0 & 1 & 0 & 0 & 0 & 0 & 0 & 0 & 1 & 0 & 0 & 1 & 0 \\
\hline Viscosia sp. 1 & 0.04 & 0.00 & 0.34 & 0 & 0 & 0 & 1 & 0 & 0 & 0 & 1 & 0 & 0 & 1 & 0 & 0 & 1 & 0 & 0 & 1 & 0 \\
\hline Viscosia sp. 2 & 0.42 & 0.53 & 0.00 & 0 & 0 & 0 & 1 & 0 & 0 & 0 & 1 & 0 & 0 & 1 & 0 & 0 & 0 & 1 & 0 & 1 & 0 \\
\hline Viscosia viscosia & 0.50 & 0.00 & 0.00 & 0 & 0 & 0 & 1 & 0 & 0 & 0 & 1 & 0 & 0 & 1 & 0 & 0 & 1 & 0 & 0 & 1 & 0 \\
\hline Viscosia sp. 3 & 0.15 & 0.00 & 0.00 & 0 & 0 & 0 & 1 & 0 & 0 & 0 & 1 & 0 & 0 & 1 & 0 & 0 & 1 & 0 & 0 & 1 & 0 \\
\hline Vasostoma sp. 1 & 0.57 & 0.57 & 0.00 & 0 & 1 & 0 & 0 & 0 & 0 & 0 & 1 & 0 & 0 & 0 & 0 & 0 & 1 & 0 & 1 & 0 & 0 \\
\hline Wieseria sp. 1 & 0.23 & 0.31 & 0.00 & 1 & 0 & 0 & 0 & 0 & 0 & 1 & 0 & 0 & 0 & 0 & 0 & 0 & 0 & 1 & 0 & 0 & 1 \\
\hline
\end{tabular}

score (Bongers et al., 1991, 1995; Pape et al., 2013); 1: species exhibiting trait; 0: species not exhibiting trait.

of each trait was plotted as an area graph, and a schematic figure was prepared to show the pattern according to the zones. For example, the shelf region favours the dominance of clavate tail shape, epigrowth feeding, slender body shape, and coloniser lifestyle with length in the range of 1-2 mm. Similarly, the OMZ shows a higher abundance of some traits, such as round tail shape, stout body shape, 2-4 mm length, and greater prevalence of omnivores and deposit feeders. A coloniser lifestyle (C-P 2-3) was more frequent, whereas persisters ( $\mathrm{C}-\mathrm{P} 4)$ decreased to lower numbers in the OMZ. In the basin, however, the sediment characteristics changed from silty sand to clay. Feeding habit and tail shape also differed in the basin (Fig. 6).

\subsection{Influence of abiotic parameters on structure and function of the nematode community}

The RELATE analyses indicated that patterns based on environmental variables were significantly related to the patterns inherent in nematode community structure both taxonomically ( $r=0.37, p=0.01)$ and functionally $(r=0.41$, $p=0.01)$. Results of BIOENV analyses revealed several notable relationships of species abundance data and biological traits with environmental parameters. For example, feeding types have the best correlation with $\mathrm{C}_{\text {org }}$, sediment $\mathrm{Chl} a$, and silt. Body size was well correlated with DO, clay, and $\mathrm{C}_{\text {org }}$, whereas tail shape was correlated with clay, DO, and silt, and body length with sand, clay, and $\mathrm{C}: \mathrm{N}$ ratio. The C-P score, however, was significantly correlated with clay and DO (Table 10). Moreover, in the case of species abundance data, bottom-water DO, clay, and $\mathrm{C}_{\text {org }}$ were proved to be the best correlated $(r=0.712, p=0.02)$. Of the 10 environmental parameters, 6 were retained for further analysis on the basis of collinearity analysis (draftsman plot). Only four variables (salinity, temperature, water $\mathrm{Chl} a$, and $\mathrm{C}: \mathrm{N}$ ratio) with a correlation $r^{2}$ value of 0.9 (considered redundant) were omitted for the DistLM procedures; the remaining variables and their pairwise spearman correlations are shown in Table 11.

Analyses with distance-based linear models (DistLM) indicated that the six abiotic variables related to the variation in nematode community structure explained $97 \%$ of its total variation, although not all variables were significant. Similarly, for the functional traits of the eight variables, six were used by the DistLM procedure to construct the best-fitting model, together explaining $96 \%$ of total variation. The Dis- 
Table 10. Results from BIOENV analyses: Spearman rank correlation (rho) and significance level ( $p$ ) between nematode biological traits and environmental variables. Values $p<0.05$ are significant. DO: dissolved oxygen; TOC: total organic carbon.

\begin{tabular}{llcc}
\hline Variable & $\begin{array}{l}\text { Environmental } \\
\text { parameters } \\
\text { DO, sediment chlorophyll }\end{array}$ & $\begin{array}{c}\text { Global test } \\
\text { (Rho) } \\
\text { Species }\end{array}$ & $\begin{array}{c}\text { Significance level of sample } \\
\text { statistics (\%) }\end{array}$ \\
\hline Feeding types & $\begin{array}{l}\text { TOC, sediment chlorophyll } \\
\text { Clay, DO }\end{array}$ & 0.44 & 3 \\
Body size & Sand, Silt, C:N ratio & 0.46 & 2 \\
Tail shape & Clay, bottom DO & 0.52 & 1 \\
Body length & Sand, clay, C:N ratio & 0.61 & 7 \\
C-P value & Clay, bottom DO & 0.53 & 8 \\
\hline
\end{tabular}

Table 11. Result of distance-based linear model (DistLM) analyses showing the influence of environmental parameters on nematode species abundance data and Bray-Curtis similarity of square-root-transformed abundance.

\begin{tabular}{|c|c|c|c|c|c|c|c|}
\hline \multicolumn{8}{|c|}{ Marginal tests } \\
\hline Variable & SS (trace) & Pseudo-F & $P$ & Prop. & & & \\
\hline $\mathrm{DO}, \mathrm{mLL}^{-1}$ & 321.67 & 23.209 & 0.068 & 0.27892 & & & \\
\hline Chl $a \mathrm{ug}^{-1}$ & 179.35 & 11.049 & 0.362 & 0.15552 & & & \\
\hline $\mathrm{C}_{\text {org }}(\%)$ & 399.65 & 31.819 & 0.008 & 0.34654 & & & \\
\hline Clay (\%) & 168.03 & 10.233 & 0.391 & 0.14571 & & & \\
\hline Silt (\%) & 121.46 & 0.70635 & 0.606 & 0.10532 & & & \\
\hline Sand $(\%)$ & 164.27 & 0.99661 & 0.426 & 0.14244 & & & \\
\hline \multicolumn{8}{|c|}{ Sequential tests } \\
\hline Variable & $R^{2}$ & SS (trace) & Pseudo-F & $\mathrm{P}$ & Prop. & Cumul. & res.df \\
\hline $\mathrm{DO}, \mathrm{mLL}^{-1}$ & 0.4647 & 6420.3 & 52.087 & 0.007 & 0.4647 & 0.4647 & 6 \\
\hline Chl $a \mu \mathrm{g}^{-1}$ & 0.50376 & 539.58 & 0.39351 & 0.81 & $3.91 \times 10^{-2}$ & 0.50376 & 5 \\
\hline $\mathrm{C}_{\mathrm{org}}(\%)$ & 0.73435 & 3185.9 & 34.722 & 0.048 & 0.23059 & 0.73435 & 4 \\
\hline Clay (\%) & 0.827 & 1280 & 16.065 & 0.22 & $9.26 \times 10^{-2}$ & 0.827 & 3 \\
\hline Silt $(\%)$ & 0.89849 & 987.83 & 14.088 & 0.34 & $7.15 \times 10^{-2}$ & 0.89849 & 2 \\
\hline Sand $(\%)$ & 0.97481 & 1054.4 & 30.302 & 0.254 & $7.63 \times 10^{-2}$ & 0.97481 & 1 \\
\hline
\end{tabular}

SS: sum of squares; F: pseudo-F; P: p value; Prop: proportion of explanation; Cumul: cumulative proportion of explanation; res.df: residual degree of freedom.

tLM analysis allowed the identification of those abiotic variables that were best correlated with the observed distribution patterns of taxonomic and functional traits of nematode species (Tables 11, 12). Results based on the abundance and presence or absence data were virtually identical; therefore, only the results based on the abundance data and functional traits are reported. Variables such as the $\mathrm{C}_{\text {org }}$ and near-bottom oxygen content showed the highest correlations $(p<0.05)$ with the nematode assemblages, whereas the functional traits were mainly explained by total organic-carbon input $(p<0.05)$. Figures 7 and 8 show the DistLM results by means of an dbRDA plot, with the species abundance and biological traits superimposed. The vectors of the environmental variables retained by the DistLM procedure as fitting the best explanatory model indicate the important role of or- ganic carbon (OC) in the slope area and $\mathrm{Chl} a$ and sand in the shelf, whereas DO and clay were important in the basin.

\section{Discussion}

\subsection{Nematode density and community structure}

Nematode density was higher in the shelf regions than on the slope or in the basin, but the lowest density was observed in the basin (2001-2546 m), where oxygen content was highest. Nematode densities and biomass along the regular slope generally decrease with water depth, surface primary productivity, and distance offshore (Soltwedel, 2000).

The role of DO is crucial in structuring meiofaunal communities, and oxygen limitation may directly control meio- 
Table 12. Result of distance-based linear model (DistLM) analyses showing the influence of environmental parameters on nematode species functional biological traits (Bray-Curtis similarity of square-root-transformed abundance).

\begin{tabular}{|c|c|c|c|c|c|c|c|}
\hline \multicolumn{8}{|c|}{ Marginal tests } \\
\hline Variable & SS (trace) & Pseudo-F & $\mathrm{P}$ & Prop. & & & \\
\hline $\mathrm{DO}, \mathrm{mLL}^{-1}$ & 6420.3 & 5.2087 & 0.013 & 0.4647 & & & \\
\hline Chl $a \mu \mathrm{g}^{-1}$ & 1424 & 0.68948 & 0.668 & 0.10307 & & & \\
\hline $\mathrm{C}_{\text {org }}(\%)$ & 4771.6 & 3.1655 & 0.048 & 0.34537 & & & \\
\hline Clay (\%) & 3635.9 & 2.1429 & 0.13 & 0.26316 & & & \\
\hline Silt (\%) & 1741.9 & 0.86558 & 0.426 & 0.12608 & & & \\
\hline Sand (\%) & 2235.4 & 1.1582 & 0.313 & 0.1618 & & & \\
\hline \multicolumn{8}{|c|}{ Sequential tests } \\
\hline Variable & $R^{2}$ & SS (trace) & Pseudo-F & $\mathrm{P}$ & Prop. & Cumul. & res.df \\
\hline $\mathrm{DO}, \mathrm{mLL}^{-1}$ & 0.4647 & 6420.3 & 5.2087 & 0.007 & 0.4647 & 0.4647 & 6 \\
\hline Chl $a \mu \mathrm{g}^{-1}$ & 0.50376 & 539.58 & 0.39351 & 0.81 & $3.91 \times 10^{-2}$ & 0.50376 & 5 \\
\hline $\mathrm{C}_{\text {org }}(\%)$ & 0.73435 & 3185.9 & 3.4722 & 0.048 & 0.23059 & 0.73435 & 4 \\
\hline Clay (\%) & 0.827 & 1280 & 1.6065 & 0.22 & $9.26 \times 10^{-2}$ & 0.827 & 3 \\
\hline Silt $(\%)$ & 0.89849 & 987.83 & 1.4088 & 0.34 & $7.15 \times 10^{-2}$ & 0.89849 & 2 \\
\hline Sand $(\%)$ & 0.97481 & 1054.4 & 3.0302 & 0.254 & $7.63 \times 10^{-2}$ & 0.97481 & 1 \\
\hline
\end{tabular}

SS: sum of squares; F: pseudo-F; P: p value; Prop: proportion of explanation; Cumul: cumulative proportion of explanation; res.df: residual degree of freedom.

fauna composition within the OMZ (Neira et al., 2001). Of the eight stations presented here, three are true OMZ stations, where DO contents are less than $0.5 \mathrm{~mL} \mathrm{~L}^{-1}$. Nematode abundance was highest in the centre of the OMZ (525 m) and decreased to its lowest value in the lower part of the OMZ (1001 m). Total metazoan meiofauna, and more specifically nematode, densities often reach maximum values at the lowest oxygen concentrations within OMZs (reviewed in Levin, 2003).

In our results, nematode densities were lower than those reported by Cook et al. (2000) for the bathyal Oman margin (range: $494-2495$ ind $10 \mathrm{~cm}^{-2}$ ). Moreover, Cook et al. (2000) found the highest abundances inside the OMZ $(700 \mathrm{~m})$, not at its centre $(400 \mathrm{~m})$, but Levin et al. (1991) found the highest densities of nematodes $\left(190\right.$ ind $\left.10 \mathrm{~cm}^{-2}\right)$ at the centre of the OMZ (at $745 \mathrm{~m}$ ), where high concentrations of organic carbon and pigments were found. In our study the combined OMZ stations showed higher density than non-OMZ stations, perhaps as a result of the ability of some species to tolerate low-oxygen conditions in order to take advantage of abundant food (Levin et al., 1991; Cook et al., 2000). Although data do not exist to identify which, if any, of the factors shapes the nematode community assemblages, we note that $\mathrm{C}_{\text {org }}\left(r^{2}=0.734, p<0.05\right)$ and near-bottom oxygen content showed the highest correlations $\left(r^{2}=0.464, p<0.05\right)$. Similarly, many previous OMZ investigations have noted a correlation between food quality and meiofaunal abundance and the absence of oxygen. For example, Cook et al. (2000) reported a strong positive correlation between nematode density and food quality, measured as the hydrogen index, along a transect through the Oman margin OMZ. Meiofaunal densities were correlated only with sediment Chl $a$ and not with oxygen or other sediment parameters along a similar OMZ transect on a seamount off Mexico (Levin et al., 1991).

Moreover, in general, nematode abundance did not follow any particular gradient though it was lowest at the deep basin stations. Generally, depth can have a major influence on nematode density (Soltwedel, 2000; Udalov et al., 2005). The pattern of quantitative distribution of nematode abundance has been described for intertidal and upper subtidal $(<50 \mathrm{~m})$ zones. The average worldwide nematode density is 1530 ind $10 \mathrm{~cm}^{-2}$; for continental slopes $(1000-2500 \mathrm{~m})$, it drops to 430 ind $10 \mathrm{~cm}^{-2}$, for lower slopes $(2500-3500 \mathrm{~m})$ it drops to 360 ind $10 \mathrm{~cm}^{-2}$, and for abyssal and hadal depths (>5000 m), it is still lower $\left(140\right.$ ind $10 \mathrm{~cm}^{-2}$ ) (Soltwedel et al., 2003; Mokievsky et al., 2004). Large-scale comparisons of nematode community structure in other ocean basins indicate that continental-shelf nematode communities differ significantly from slope communities (Vanreusel et al., 2010).

The nMDS based on nematode species abundance and presence or absence separated the three zones, and the difference was confirmed by PERMANOVA ( $p=0.03$ ). Group 1 comprised the stations of the shelf region, with the exception of the deepest shelf station, which was grouped with the slope area to form the OMZ stations, where opportunistic species such as Pselionema sp. 1, Choanolaimus sp. 2, Halichoanolaimus sp. 1, Cobbia dentata, Daptonema sp. 1, Trissonchulus sp. 1, and Minolaimus sp. 1 were found. The exclusive presence of these species in the OMZ may be the 
result of OMZ sediments that favour the success of nematode species that are tolerant (colonists) or adapted (endemics). In addition to the seven species found exclusively in the OMZ, a number of species were found exclusively outside it. One might speculate that OMZs have isolated hypoxia-tolerant nematode species as a result of their different life strategies, small size, lower mobility, and lack of pelagic larval stage. Some species may therefore be able to tolerate the oxygen minima, while others cannot. The exact mechanisms of adaptation to or preferences of species for the anoxic environment remains unclear, however. Several authors have pointed out that nematode species can successfully cope with anoxic conditions by developing appropriate physiological and behavioural mechanisms (e.g. symbiosis with bacteria, which we also observed, and migration to "oxygen islands," sensu Reise and Ax (1979) and Wetzel et al. (1995)). Mouthless and gutless nematodes carrying endosymbionts have been observed previously in deep-sea environments (Ingels et al., 2011).

Our study did not reveal that nematode species have developed any obvious adaptations, but they must have a certain tolerance for anoxic conditions. The dominant species in the OMZ, such as Terschellingia longicaudata, Desmodora sp. 1, and Sphaerolaimus gracilis, have been recognised extensively as tolerant (Schratzberger et al., 2006). Adaptations in Terschellingia sp. and Sphaerolaimus sp. - the presence of dark, often multilayered intracellular globules in the intestinal cells - are often pointed out as typical for sulfidic muds, but their significance is ambiguous and their adaptive value for the thiobiotic life disputed. Moreover, the deposition of insoluble metal sulfides in intracellular inclusions in Terschellingia longicaudata has been suggested to be a mechanism of detoxification of sulfide (Nicholas et al., 1987). Further, some specimens belonging to the OMZ showed some morphological differences, whereas others were observed to have epibionts, like the majority of specimens of Desmodora sp. Some species were observed to have unidentified blackish gut content. A small nematode was found in the gut of Metalinhomoeus sp. 1, which has a very small buccal cavity.

Even though the majority of the species identified in our study were common and recorded from each of the three benthic zones, the IndVal index identified some species that can serve as indicators of the shelf, slope, and basin. The IndVal index is an important tool for ecosystem monitoring and assessments because it expresses a value for species or genera that can characterise the particular environment (Dufrêne and Legendre, 1997). The genus Acantholaimus (Acantholaimus mirabilis significantly associated with the basin; $p=0.005$ ) is quite typical of the deep sea and is rarely found in shallow water; only one species has been described from intertidal sediments (Platt and Zhang, 1982). The genus Acantholaimus increased in relative abundance with increasing depth in many deep-sea areas (Soetaert and Heip, 1995). Moreover, Viscosia viscosia was a good indicator of the shelf because it often inhabits the surface layers of sediment and is apparently capable of floating (Fonsêca-Genevois et al., 2006).

The IndVal index reaches its maximum $(100 \%)$ when individuals of the target species are observed at all the sites of one group and at no sites of any other (Dufrêne and Legendre, 1997). For those species that were found in equal proportions in each of the three zones, the association with the set of all the sites cannot be statistically tested because no external group is available for comparison, so these species cannot be treated as indicators of a particular habitat but can be considered cosmopolitan.

Species diversity was higher on the shelf than on the slope or in the basin. This difference appears to be partly due to the bottom-water DO gradient, which includes values that are below the oxygen tolerance of many nematode species. Therefore very few species were present on the slope, especially inside the OMZ. Moreover, the results of a macrofauna study from this area have shown that different physiographic provinces and an oxygen gradient have a greater influence on the species composition and diversity than do other oceanographic conditions (Ingole et al., 2010). The species number and diversity were positively correlated with DO and negatively correlated with $\mathrm{Chl} a$ and $\mathrm{C}_{\mathrm{org}}$. Species diversity is not always correlated with the organic enrichment of the sediment; Schratzberger and Warwick (1998) observed a decrease in species richness possibly due to anoxia and the release of toxic substances under high input of organic loading. The lower species diversity of the nematode community under hypoxic conditions is accompanied by the high dominance by a very few highly abundant species. Nematode species especially from OMZs seem able to develop some functional adaptations as they must have a certain tolerance for sulfidic and/or anoxic conditions.

\subsection{Functional Traits}

Marine organisms are often challenged by fluctuations in the aquatic environment, which they must survive, regulate, tolerate, or resist (Odiete, 1999). The different gradients of biological, chemical, and physical properties in the aquatic environment complicate the situation. One major challenge is the depletion of DO, but some organisms are able to cope by means of extreme changes in their body morphology and physiology (Schneider and Bush-Brown, 2003). In our study the distinct features of the three zones were also reflected in the functional-trait approach.

Deposit feeders were more abundant in shelf and basin areas than at most of the slope-area (OMZ) stations, where predators or omnivores were most abundant. Epigrowth feeders were more abundant at lower shelf stations and at some stations of the OMZ region, probably because of the higher organic content of the sediment. OMZs often support mats of large sulfur-oxidising bacteria, including Thioploca, Beggiatoa, and Thiomargarita, which are often conspicuous features of the sediment surface in OMZs (Levin, 2003). These 
bacterial mats have been observed previously at the Oman margin (Levin et al., 1997).

Several previous researchers have speculated that Thioploca mats represent a significant source of food for the $\mathrm{OMZ}$ faunas of the Peru-Chile margin (Gallardo, 1977; Arntz et al., 1991; Levin et al., 2000). Epigrowth feeders have been found to feed on microbiota by scraping them off solid surfaces or mucus threads with their teeth. Higher amounts of organic matter enriched the growth of diatoms and ciliates in the OMZ, which can contribute significantly to food for epigrowth feeders, but in general the proportion of predators or omnivores and epigrowth feeders was low in our study. Gambi et al. (2003) suggested that the low prevalence of predatory and omnivorous nematodes can be attributed to the absence of freshly dead organisms.

The dominance of the deposit feeders in silty sediments of the basin is in agreement with results from most previous deep-sea studies (Tietjen, 1984; Jensen, 1988; Netto et al., 2005). Jensen (1988) found that the deep-sea fauna in the Norwegian Sea was dominated by deposit feeders and included few predators and scavengers. Deposit feeders were also the dominant group in the Puerto Rico trench and the Hatteras abyssal plain. The selective deposit feeders (microvores) are the main consumers of deep-sea bacteria (Ingels et al., 2011) because deposit-feeding nematodes have minute buccal cavities, restricting them to small particulate food or dissolved organic matter. The relative proportion of each of the four Wieser feeding types in a community depends on the nature of the available food, which may perhaps explain their prominence on exposed substrata (Platt and Warwick, 1980). BIOENV analysis showed that feeding types were well correlated with $\mathrm{C}_{\text {org }}$, sediment chlorophyll, and silt, which represent the substratum condition and feeding content.

In nematodes, the tail plays an important role in locomotion, which in turn depends on sediment type (Riemann, 1974). Our BIOENV analysis revealed that tail type in nematodes was significantly correlated with sediment texture and $\mathrm{C}_{\text {org }}$. Nematodes with clavate tail shape dominated at each depth, although to a greater degree in the shelf and basin regions (Table 3). Riemann (1974) considered this type of tail morphology to be typical of the inhabitants of the interstitial spaces in sand. The conical tail shape was observed more frequently in slope regions than on the shelf; again, Riemann (1974) suggested that a conical tail could be a special adaptation to fine sand and muddy sediments, where only an incomplete interstitial system exists. The proportion of the long-tail shape and round shape was much lower than that of the above-mentioned categories, but the scant availability of data on this aspect prevents comparison and any generalised conclusion.

Vanhove et al. (1995) and Soetaert et al. (2002) noted that length and width are important functional attributes for describing chemical stress, metabolic rate, the ability to move or migrate, and vulnerability to predation. In fact, the size of animals is an integrative feature strongly correlated with their morphology, locomotion, feeding mode, and other characteristics. Most authors have related nematode length and width to granulometry, in concordance with the BIOENV analysis, which revealed that body shape was significantly correlated with sand and clay.

In our case, slender nematodes were dominant in the shelf region, and their lengths were mainly in the ranges of 2-4 and 1-2 $\mathrm{mm}$. The slope area harboured more long and thin nematodes, as was the case in earlier studies (Jensen, 1987). Pronounced body elongation in nematodes and a greater surface: volume ratio in thiobiotic species are adaptive characteristics related to low oxygen partial pressure and epidermal uptake of dissolved organic matter (Jensen, 1987). Further, increased length under suboxic or anoxic conditions reflects increased mobility. The increasing proportions of long and thin nematodes from the shelf to deeper stations possibly signify that a large body size could facilitate easy burrowing through the sediment, but below the OMZ, the long and thin nematodes were even more abundant, suggesting a relationship with fine clay and silt sediments where only an incomplete interstitial system exists. In a general comparison, however, the organisms inhabiting the oxygenated environments are found to be of a size and shape different from those of organisms from the OMZs (Schneider and Bush-Brown, 2003).

Some biological traits, usually less accessible but with direct functional roles (Hodgson et al., 1999) such as life history, are widely used in freshwater and terrestrial habitats (Bongers, 1990). Over $75 \%$ of all identified individuals attained a C-P score of 2 to 3 . Animals from the OMZ represented a higher contribution to this range. Under eutrophic conditions, colonisers are more numerous, whereas the number of persisters remains constant, but persisters (scores 3-4) were more often seen in deeper waters, perhaps because most deep-water nematodes are deposit feeders, which often score 3-4 on the C-P scale (Bongers et al., 1991). Bongers and Ferris (1999) also distinguished between two types of opportunists: enrichment and general opportunists. The family Monhysteridae was represented by only two species (Diplolaimella sp. 1, Diplolaimelloides sp. 1) in the present study and was classified as C-P class 2 (general opportunist) (Bongers, 1990).

The trait matrix revealed that some combinations of functional groups were significantly correlated. A stout body shape was positively correlated with a clavate, long tail and non-selective feeding type because these traits showed the same increasing trend from shelf to basin. A similar trend was evident for long and thin tail shape with a length of $4 \mathrm{~mm}$ and a clavate shape with non-selective feeding, which showed very high positive correlation (0.8). In general, large organisms were more prominent at eutrophic sites, whereas smaller organisms became more dominant in oligotrophic environments (Thiel, 1975). This pattern clearly explains the abundance of long and thin nematodes in the slope region of the Arabian Sea. The analysis of a combination of bio- 
logical traits seems to be a more reliable approach for assessing the functional structure of nematode communities than relying on single functional groups (Schratzberger et al., 2007). Our schematic model presents the trait responses in different zones. The outcome confirmed that functional-trait analysis is of additional ecological importance, and the information captured by the biological-trait matrix was not a simple reflection of the information contained in taxonomy. Nematodes with different functional characteristics differ in their abilities to respond to environmental stresses and disturbance, thereby providing resilience to the community. Environmental conditions thus influence the importance of functional complementarity in structuring communities (Hooper et al., 2005).

\subsection{Environmental parameters and their impact on the nematode community}

The Arabian Sea OMZ extends over $285000 \mathrm{~km}^{2}$ and is the second most intense OMZ in the world tropical ocean (Kamykowski and Zentara, 1990). In this region oxygen concentrations and organic matter are inversely correlated (Levin and Gage, 1998), and this condition represents a major challenge for the adaptation of many species in OMZs.

Results of BIOENV analysis revealed the best correlation between the functional trait and individual parameter, i.e. the importance of $\mathrm{C}_{\text {org }}$, sediment chlorophyll, and silt content for feeding strategy. Organic enrichment is an important ecological process in marine sediments (Kelly and Nixon, 1984), and it is related to the presence of fine sediment, a low hydrodynamic regime, and low DO (Snelgrove and Butman, 1994). Nematode assemblages were dominated by deposit-feeding organisms, which can make full use of both particulate organic matter and the associated bacterial biomass. Moreover, the content of organic matter can partially explain the spatial patterns of the distribution of free-living nematodes in some habitats (Ólafsson and Elmgren, 1997; Schratzberger et al., 2006). Body size was well correlated with DO, clay, and $\mathrm{C}_{\text {org }}$, whereas tail shape was correlated with clay, DO, and silt and body length with sand, clay, and the $\mathrm{C}: \mathrm{N}$ ratio. This pattern shows the properties of sediment-related factors, which are also important for morphological characteristics of species. The highest values of sediment $\mathrm{C}_{\text {org }}$ on the slope are probably due to the diverse topographic features there, and the associated hydrodynamic processes play an important role in the enrichment of $\mathrm{C}_{\text {org }}$ (Rao and Veerayya, 2000). The DistLM analysis indicated that DO concentration and organic content were the only parameters that were significantly correlated with nematode species and functional data, respectively.

\section{Conclusions}

Free-living nematodes are an abundant and diverse component of the meiofauna on the western continental margin of the Arabian Sea. They follow the general trends of decreasing nematode abundance and diversity with increasing depth observed among other benthic taxa along the continental shelf and in the deep sea. We aimed to determine the nematode community structure and functional traits in the Indian western continental margin, including the OMZ. The effects of heterogeneous environments were more evident in taxonomic groups than in functional traits. Although numerous factors could be important for the formation and persistence of nematode communities, the presence of the OMZ seems to be paramount. Along with organic content, DO plays a vital role in structuring nematode communities and certain functional adaptations among different species may play an important role in determining the ecosystem function. From our study, no single parameter can be determined to cause the observed patterns in the three benthic zones. Our results support the previous finding that nematodes are the taxon most tolerant of environmental variation but that within the nematode community only a few species can tolerate oxygen minima. Our study has provided the first insight into the ecosystem functional diversity from coastal to deep-sea nematode fauna from the Arabian Sea, but only further work will reveal whether this pattern is broadly applicable.

Acknowledgements. We thank the Director, CSIR-National Institute of Oceanography, Goa, India, for the use of scientific facilities and the Ministry of Earth Sciences (Government of India) for ship-board facilities.

Edited by: L. Levin

\section{References}

Anderson, M.: PERMANOVA: Permutational multivariate analysis of variance, Department of Statistics, Auckland, 2005.

Anderson, M. J., Gorley, R. N., and Clarke, K. R.: PERMANOVA+ for PRIMER: guide to software and statistical methods, PRIMER-E Ltd., Plymouth, UK, p. 214, 2008.

Arntz, W., Tarazona, J., Gallardo, V. A., Flores, L. A., and Salzwedel, H.: Benthos communities in oxygen deficient shelf and upper slope areas of the Peruvian and Chilean Pacific coast, and changes caused by El Nino, In: Modern and ancient continental shelf anoxia, edited by: Tyson, R. V. and Pearson, T. H., Geological Society Special, 58, 131-154, 1991.

Banse, K., Naqvi, S. W. A., Narvekar, P. V., Postel, J. R., and Jayakumar, D. A.: Oxygen minimum zone of the open Arabian Sea: variability of oxygen and nitrite from daily to decadal timescales, Biogeosciences, 11, 2237-2261, doi:10.5194/bg-112237-2014, 2014. 
Bongers, T.: The maturity index: an ecological measure of environmental disturbance based on nematode species composition, Oecologia, 83, 14-19, 1990.

Bongers, T., and Ferris, H.: Nematode community structure as a bioindicator in environmental monitoring, Trends Ecol. Evol., 14, 224-228, 1999.

Bongers, T., Alkemade, R., and Yeates, G. W.: Interpretation of disturbance-induced maturity decrease in marine nematode assemblages by means of the Maturity Index, Mar. Ecol.-Prog. Ser., 76, 135-142, 1991.

Bongers, T., de Goede, R. G. N., Korthals, G. W., and Yeates, G. W.: Proposed changes of c-p classification for nematodes, Russ. J. Nematol., 3, 61-62, 1995.

Boström, C., Lastuniemi, M., and Bonsdorff, E.: Infaunal responses to habitat structure: a study of life-history traits and population dynamics of Corophium volutator (Pallas), Mar. Biol. Res., 2, 398-410, 2006.

Bray, J. R. and Curtis, J. T.: An ordination of the upland forest communities of southern Wisconsin, Ecol. Monogr., 27, 325-349, 1957.

Bremner, J.: Species' traits and ecological functioning in marine conservation and management, J. Exp. Mar. Biol. Ecol., 366, 3747, 2008.

Bremner, J., Rogers, S. I., and Frid, C. L. J.: Assessing functional diversity in marine benthic ecosystems: a comparison of approaches, Mar. Ecol.-Prog. Ser., 254, 11-25, 2003.

Chalcraft, D. R. and Resetarits Jr., W. J.: Predator identity and ecological impacts: functional redundancy or functional diversity, Ecology, 84, 2407-2418, 2003.

Clarke, K. R.: Non-parametric multivariate analysis of changes in community structure, Aust. J. Ecol., 18, 117-143, 1993.

Clarke, K. R. and Ainsworth, M.: A method of linking multivariate community structure to environmental variables, Mar. Ecol.Prog. Ser., 92, 205-219, 1993.

Clarke, K. R. and Gorley, R. N.: PRIMER v6*: User Manual/Tutorial, Version 6, PRIMER-E Ltd., Plymouth, UK, p. 192, 2006.

Clarke, K. R. and Green, R. H.: Statistical design and analysis for a "biological effects" study, Mar. Ecol.-Prog. Ser., 46, 213-226, 1988.

Cook, A. A., Lambshead, P. J. D., Hawkins, L. E., Mitchell, N., and Levin, L. A.: Nematode abundance at the oxygen minimum zone in the Arabian Sea, Deep-Sea Res. Pt. II, 47, 75-85, 2000.

Danovaro, R., Gambi, C., Dell'Anno, A., Corinaldesi, C., Fraschetti, S., Vanreusel, A., Vincx, M., and Gooday, A.: Exponential decline of deep-sea ecosystem functioning linked to benthic biodiversity loss, Curr. Biol., 18, 1-8, 2008.

De Cáceres, M., Legendre, M. P., and Moretti, M.: Improving indicator species analysis by combining groups of sites, Oikos, 119, 1674-1684, 2010.

de Jonge, V. N., Elliott, M., and Brauer, V. S.: Marine monitoring: its shortcomings and mismatch with the EU Water Framework Directive's objectives, Mar. Pollut. Bull., 53, 5-19, 2006.

De Troch, M., Roelofs, M., Riedel, B., and Grego, M.: Structural and functional responses of harpacticoid copepods to anoxia in the Northern Adriatic: an experimental approach, Biogeosciences, 10, 4259-4272, doi:10.5194/bg-10-4259-2013, 2013.

Dimitriadou, E., Hornik, K., Leisch, F., Meyer, D., and Weingessel, A.: Misc. functions of the Department of Statistics (e1071),
TU Wien, R package version, 1.6., http://CRAN.Rproject.org/ package $=\mathrm{e} 1071$ (last access: 6 June 2015), 2015.

Dufrêne, M. and Legendre, P.: Species assemblages and indicator species: the need for a flexible asymmetrical approach, Ecol. Monogr., 67, 345-366, 1997.

Fonsêca-Genevois, V., Somerfield, P. J., Baeta Neves, M. H., Coutinho, R., and Moens, T.: Colonization and early succession on artificial hard substrata by meiofauna, Mar. Biol., 148, 10391050, 2006.

Gallardo, V. A.: Large benthic microbial communities in sulphide biota under Peru-Chile Subsurface Countercurrent, Nature, 268, 331-332, 1977.

Gambi, C., Vanreusel, A., and Danovaro, R.: Biodiversity of nematode assemblages from deep-sea sediments of the Atacama Slope and Trench (South Pacific Ocean), Deep-Sea Res. Pt. I, 50, $103-$ 117, 2003.

Giere, O.: Meiobenthology, Springer-Verlag, Berlin, Heidelberg, 328 pp., 1993.

Heip, C., Vincx, M., and Vranken, G.: The ecology of marine nematodes, Oceanogr. Mar. Biol., 23, 399-489, 1985.

Helly, J. J. and Levin, L. A.: Global distribution of naturally occurring marine hypoxia on continental margins, Deep-Sea Res. Pt. I, 51, 1159-1168, 2004.

Hodgson, J. G., Wilson, P. J., Hunt, R., Grime, J. P., and Thompson, K.: Allocating C-S-R plant functional types: a soft approach to a hard problem, Oikos, 85, 282-294, 1999.

Holm-Hansen, O. and Riemann, B.: Chlorophyll a determination: improvements in methodology, Oikos, 30, 438-447, 1978.

Hooper, D. U., Chapin, F. S., Ewel, J. J., Hector, A., Inchausti, P., Lavorel, S., Lawton, J. H., Lodge, D. M., Loreau, M., Naeem, S., Schmid, B., Setalä, H., Symstad, A. J., Vandermeer, J., and Wardle, D. A.: Effects of biodiversity on ecosystem functioning: a consensus of current knowledge, Ecol. Monogr., 75, 3-35, 2005.

Ingels, J., Billett, D.S.M., Van Gaever, S., Vanreusel, A.: An insight into the feeding ecology of deep-sea canyon nematodes-results from field observations and the first in-situ ${ }^{13} \mathrm{C}$ feeding experiment in the Nazaré Canyon, J. Exp. Mar. Biol. Ecol., 396, 185193, 2011.

Ingole, B. S., Sautya, S., Sivadas, S., Singh, R., and Nanajkar, M.: Macrofaunal community structure in the Western Indian continental margin including the oxygen minimum zone, Mar. Ecol., 31, 148-166, 2010.

Jensen, P.: Feeding ecology of free-living aquatic nematodes, Mar. Ecol.-Prog. Ser., 35, 187-196, 1987.

Jensen, P.: Nematode assemblages in the deep-sea benthos of Norwegian Sea, Deep-Sea Res., 35, 1173-1184, 1988.

Kamykowski, D. and Zentara, S. J.: Hypoxia in the world ocean as recorded in the historical dataset, Deep-Sea Res., 37, 1861-1874, 1990.

Kelly, J. R. and Nixon, S. W.: Experimental studies of the effect of organic deposition on the metabolism of a coastal marine bottom community, Mar. Ecol.-Prog. Ser., 17, 157-169, 1984.

Levin, L. A.: Oxygen minimum zone benthos: adaptation and community response to hypoxia, Oceanogr. Mar. Biol., 41, 1-45, 2003.

Levin, L. A. and Gage, J. D.: Relationships between oxygen, organic matter and the diversity of bathyal macrofauna, Deep-Sea Res., 45, 129-163, 1998 
Levin, L. A., Huggett, C. L., and Wishner, K. F.: Control of deepsea benthic community structure by oxygen and organic-matter gradients in the eastern Pacific Ocean, J. Mar. Res., 49, 763-800, 1991.

Levin, L., Gage, J., Lamont, P., Cammidge, L., Martin, C., Patience, A., and Crooks, J.: Infaunal community structure in a low-oxygen, organic-rich habitat on the Oman continental slope, NW Arabian Sea, in: The responses of marine organisms to their environments: Proceedings of the 30th European Marine Biology Symposium, University of Southampton, Southampton, UK, 223-230, 1997.

Levin, L. A., Gage, J. D., Martin, C., and Lamont, P. A.: Macrobenthic community structure within and beneath the oxygenminimum zone, NW Arabian Sea, Deep-Sea Res. Pt. II, 47, 189226, 2000.

Levin, L. A., Etter, R. J., Rex, M. A., Gooday, A. J., Smith, C. R., Pineda, J., Stuart, C. T., Hessler, R. R., and Pawson, D.: Environmental influences on regional deep sea species diversity, Annu. Rev. Ecol. Syst., 32, 51-93, 2001.

Margalef, R.: Perspectives in Ecological Theory. University of Chicago Press, Chicago, p. 111, 1968.

McArdle, B. and Anderson, M.: Fitting multivariate models to community data: a comment on distance-based redundancy analysis, Ecol. Lett., 82, 290-297, 2001.

Mokievsky, V. O., Udalov, A. A., and Azovsky, A. I.: On the quantitative distribution of meiobenthos on the shelf of the World Ocean, Oceanology, 44, 110-120, 2004.

Moodley, L., van der Zwaan, G. J., Herman, P. M. J., Kempers, L., and van Breugel, P.: Differential response of benthic meiofauna to anoxia with special reference to Foraminifera (Protista: Sarcodina), Mar. Ecol.-Prog. Ser., 158, 151-163, 1997.

Murrell, M. C. and Fleeger, J. W.: Meiofaunal abundance on the Gulf of Mexico continental shelf affected by hypoxia, Cont. Shelf Res., 9, 1049-1062, 1989.

Neira, C., Sellanes, J., Levin, L. A., and Arntz, W. A.: Meiofaunal distributions on the Peru Margin: relationship to oxygen and organic matter availability, Deep-Sea Res., 48, 2453-2472, 2001.

Neira, C., King, I., Mendoza, G., Sellanes, J., De Ley, P., and Levin, L. A.: Nematode community structure along a central Chile margin transect influenced by the oxygen minimum zone, Deep-Sea Res. Pt. I, 78, 1-15, 2013.

Netto, S. A., Gallucci, F., and Fonseca, G. F. C.: Meiofauna communities of continental slope and deep-sea sites off SE Brazil, Deep-Sea Res., 52, 845-859, 2005.

Nicholas, W. L., Goodchild, D. J., and Steward, A.: The mineral composition of intracellular inclusions in nematodes from thiobiotic mangrove mud-flats, Nematologica, 33, 167-179, 1987.

Odiete, W. O.: Environmental physiology of animals and pollution, Diversified Resources Ltd., Lagos, 261 pp., 1999.

Ólafsson, E. and Elmgren, R.: Seasonal dynamics of sublittoral meiobenthos in relation to phytoplankton sedimentation in the Baltic Sea, Estuar. Coast. Shelf. S., 45, 149-164, 1997.

Qasim, S. Z.: Biological productivity of the Indian Ocean, Ind. J. Mar. Sci., 6, 122-137, 1977.

Pape, E., Bezerra, T. N., Jones, D. O. B., and Vanreusel, A.: Unravelling the environmental drivers of deep-sea nematode biodiversity and its relation with carbon mineralisation along a longitudinal primary productivity gradient, Biogeosciences, 10, 31273143, doi:10.5194/bg-10-3127-2013, 2013.
Paulmier, A. and Ruiz-Pino, D.: Oxygen minimum zones (OMZs) in the modern ocean, Prog. Oceanogr., 80, 113-128, 2009.

Pielou, E. C.: Species diversity and pattern diversity in the study of ecological succession, J. Theor. Biol., 10, 372-383, 1966.

Platt, H. M. and Warwick, R. M.: The significance of freeliving nematodes to the littoral ecosystem, in: Price, J. H., Irvine, D. E. G., and Famham, W. F., The shore environment, Vol. 2, Ecosystems, Academic Press, London, 729-759, 1980.

Platt, H. M. and Warwick, R. M.: Free-living marine nematodes Part I: British Enoplids, in:, Kermack, D. M. and Barnes, R. S. K., Synopses of the British fauna (New Series), Cambridge University Press, 307 pp., 1983.

Platt, H. M. and Zhang, Z. N.: New species of marine nematodes from Loch Ewe, Scotland, Bulletin of the British Museum of Natural History (Zoology), 42, 227-246, 1982.

R Development Core Team: R.: A language and environment for statistical computing. R Foundation for Statistical Computing, Vienna, www.R-project.org/ (last access: 11 June 2015), 2010.

Rao, B. R. and Veerayya, M.: Influence of marginal highs on the accumulation of organic carbon along the continental slope off western India, Deep-Sea Res. Pt. II, 47, 303-327, 2000.

Reichart, G. L., Lourens, L. J., and Zachariasse, W. J.: Temporal variability in the northern Arabian Sea oxygen minimum zone (OMZ) during the last 225,000 years, Paleoceanography, 13, 607-621, 1998.

Reise, K. and Ax, P.: A meiofaunal "thiobios" limited to the anaerobic sulfide system of marine sand does not exist, Mar. Biol., 54, 225-237, 1979.

Riemann, F.: On hemisessile nematodes with flagelliform tails living in marine soft bottoms and micro-tubes found in deep sea sediments, Mikrofauna Meeresboden, 40, 1-15, 1974.

Ryther, J. H. and Menzel, D. W.: On the production, composition, and distribution of organic matter in the Western Arabian Sea, Deep-Sea Res., 12, 199-209, 1965.

Schneider, C. C. and Bush-Brown, S.: Oxygen minimum zones, The Traprock, 2, 19-23, 2003.

Schratzberger, M. and Warwick, R. M.: Effects of the intensity and frequency of organic enrichment on two estuarine nematode communities, Mar. Ecol.-Prog. Ser., 164, 83-94, 1998.

Schratzberger, M., Warr, K., and Rogers, S. I.: Patterns of nematode populations in the southwestern North Sea and their link to other components of the benthic fauna, J. Sea Res., 55, 113-127, 2006.

Schratzberger, M., Warr, K., and Rogers, S. I.: Functional diversity of nematode communities in the southwestern North Sea, Mar. Environ. Res., 63, 368-389, 2007.

Shannon, C. E. and Weaver, W.: The Mathematical Theory of Communication, University of Illinois Press, Urbana, Illinois, 144 pp., 1963.

Shetye, S. R. and Shenoi, S. C. C.: Seasonal cycle of surface circulation in the coastal north Indian Ocean, Proc. Ind. Acad. Sci. Earth Planet. Sci., 97, 53-62, 1988.

Snelgrove, P. V. R. and Butman, C. A.: Animal-sediment relationships revisited: cause versus effects, Oceanogr. Mar. Biol., 32, 111-177, 1994.

Soetaert, K. and Heip, C.: Nematode assemblages of deep-sea and shelf break sites in the North Atlantic and Mediterranean Sea, Mar. Ecol.-Prog. Ser., 125, 171-183, 1995.

Soetaert, K., Middelburg, J., Wijsman, J., Herman, P., and Heip, C.: Ocean margin early diagenetic processes and models, in: Ocean 
margin systems, edited by: Wefer, G., Billett, D., Hebbeln, D., Jørgensen, B. B., and von Weesing, T. J., Springer Verlag, Berlin, 157-177, 2002.

Soltwedel, T.: Metazoan meiobenthos along continental margins: a review, Prog. Oceanogr., 46, 59-84, 2000.

Soltwedel, T., Miljutina, M., Mokievsky, V., Thistle, D., and Vopel, K.: The meiobenthos of the Molloy deep (5600 M) Fram Strait, Arctic Ocean, Vie Milieu, 53, 1-13, 2003.

Strickland, J. D. H. and Parsons, T. R.: A practical handbook of seawater analysis, B. Fish. Res. Board Can., 167, 1-311, 1968.

Thiel, H.: The size structure of the deep-sea benthos, Int. Rev. Ges. Hydrobio., 60, 575-606, 1975.

Thistle, D. and Sherman, K. M.: The nematode fauna of a deep-sea site exposed to strong near-bottom currents, Deep-Sea Res., 32, 1077-1088, 1985.

Tietjen, J. H.: Distribution and species diversity of deep-sea nematodes in the Venezuela basin, Deep-Sea Res., 31, 119-132, 1984.

Udalov, A. A., Azovsky, A. I., and Mokievsky, V. O.: Depth-related pattern in nematode size: what does the depth itself really mean? Prog. Oceanogr., 67, 1-23, 2005.

Van Colen, C., Montserrat, F., Vincx, M., Herman, P. M. J., Ysebaert, T., and Degraer, S.: Macrobenthic recovery from hypoxia in an estuarine tidal mudflat, Mar. Ecol.-Prog. Ser., 372, 31-42, 2008.

Vanaverbeke, J., Bezerra, T. N., Braeckman, U., De Groote, A., De Meester, N., Deprez, T., Derycke, S., Gilarte, P., Guilini, K., Hauquier, F., Lins, L., Maria, T., Moens, T., Pape, E., Smol, N., Taheri, M., Van Campenhout, J., Vanreusel, A., Wu, X., and Vincx, M.: NeMys: World Database of Free-Living Marine Nematodes, 10-30, 2015.

Vanhove, S., Wittoeck, J., Desmet, G., Van Den Berghe, B., Herman, R. L., Bak, R. P. M., Nieuwland, G., Vosjan, J. H., Boldrin, A., Rabitti, S., and Vincx, M.: Deep sea meiofauna communities in Antarctica: structural analysis and the relation with the environment, Mar. Ecol.-Prog. Ser., 127, 65-76, 1995.
Vanreusel, A., Fonseca, G., Danovaro, R., Silva, M. C. D., Esteves, A. M., Ferrero, T., Gad, G., Galtsova, V., Gambi, C., Genevois, V. D. F., Ingels, J., Ingole, B., Lampadariou, N., Merckx, B., Miljutin, D., Miljutina, M., Muthumbi, A., Netto, S., Portnova, D., Radziejewska, T., Raes, M., Tchesunov, A.,Vanaverbeke, J., van Gaever, S., Venekey, V., Bezerra, T. N., Flint, H., Copley, J., Pape, E., Zeppilli, D., Martinez, P. A., and Galeron, J.: The contribution of deep-sea macrohabitat heterogeneity to global nematode diversity, Mar. Ecol., 31, 6-20, 2010.

Vincx, M. and Hall, G. S.: Meiofauna in marine and fresh water sediments, in: Methods for the examination of organismal diversity in sils and sediments, CAB International, edited by: Vincx, M. and Hall, G. S., University Press, Cambridge, 214-248, 1996.

Vincx, M., Bett, B. J., Dinet, A., Ferrero, T., Gooday, A. J., Lambshead, P. J. D., Pfannkuche, O., Soltwedel, T., and Vanreusel, A.: Meiobenthos of the deep northeast Atlantic, Adv. Mar. Biol., 30, 2-88, 1994.

Wetzel, M. A., Jensen, P., and Giere, O.: Oxygen/sulfide regime and nematode fauna associated with Arenicola marina burrows: new insights in the thiobios case, Mar. Biol., 124, 301-312, 1995

Wieser, W.: Die Beziehung zwischen Mundhohlen gestalt, Ernahrungsweise und Vorkommen bei frelebenden marinen Nernatoden, Ark. Zool., 4, 439-484, 1953.

Wishner, K., Levin, L., Gowing, M., and Mullineaux, L.: Involvement of the oxygen minimum in benthic zonation on a deep seamount, Nature, 346, 57-59, 1990.

Zettler, M. L., Bochert, R., and Pollehne, F.: Macrozoobenthos diversity in an oxygen minimum zone off northern Namibia, Mar. Biol., 156, 1949-1961, 2009. 